\title{
Sea anemones (Cnidaria: Actiniaria, Corallimorpharia, Ceriantharia, Zoanthidea) from marine shallow-water environments in Venezuela: new records and an updated inventory
}

\author{
Ricardo González-Muñoz ${ }^{1,2^{*}}$, Nuno Simões ${ }^{3}$, Edlin J. Guerra-Castro ${ }^{4}$, Carlos Hernández-Ortíz ${ }^{4}$, \\ Gabriela Carrasquel ${ }^{4}$, Enio Mendez ${ }^{4}$, Carlos Lira ${ }^{4}$, Martin Rada ${ }^{5}$, Iván Hernández ${ }^{5,6}$, Sheila M. Pauls ${ }^{7}$, \\ Aldo Croquer ${ }^{8}$ and Juan J. Cruz-Motta ${ }^{8}$
}

\begin{abstract}
Background: This study compiles the diversity of sea anemones in different shallow habitats (i.e. rocky shores, coral reefs, mangroves and sandy bottoms) in several locations of Venezuela, including the most important marine reserves of Venezuela: Morrocoy National Park, Mochima National Park, Archipiélago de Los Roques National Park, Laguna de La Restinga National Park, Isla de Cubagua, and Chichiriviche de la Costa.

Results: Twenty-six species of sea anemones sensu lato were documented, from which only two actiniarian species are newly recorded in Venezuela. In addition, specimens of the scientific collection of the Museo Oceanológico Hermano Benigno Román, of Isla de Margarita, Venezuela, were examined and its taxonomic status updated.

Conclusions: The diversity of sea anemones in Venezuela is updated to 44 species. An illustrated guide of living specimens and short descriptions of the external anatomy of the specimens is included to facilitate sea anemone species identification in the field and to provide a base line for ecological studies that require accurate identification to species level.
\end{abstract}

Keywords: Caribbean Sea, Coral reefs, Biodiversity, Benthic invertebrate fauna

\section{Background}

Sea anemones are among the cnidarian groups in benthic assemblages of the Caribbean Sea, being found in a wide range of coastal habitats, including seagrass meadows, rocky bottoms, coral rubble, coral reefs, sandy patches, mangrove zones and artificial substrates. Although several inventories of sea anemones

\footnotetext{
* Correspondence: ricordea.gonzalez@gmail.com

${ }^{1}$ Departamento de Ciencias de la Sustentabilidad, El Colegio de la Frontera Sur (ECOSUR), Laboratorio de Biodiversidad y Cambio Climático, Avenida Rancho Polígono 2A, Ciudad Industrial, Lerma Campeche, Campeche C.P. 24500, México

Laboratorio de Biología de Cnidarios, Facultad de Ciencias Exactas y Naturales, Universidad Nacional de Mar del Plata, Funes 3250, Mar del Plata C.P. 7600 , Argentina

Full list of author information is available at the end of the article
}

species have been made from many coastal and coral reef localities along the Caribbean Basin and Gulf of Mexico (González-Muñoz et al. 2012, 2013), many areas remain poorly studied, such as the Caribbean coast of Venezuela (Losada \& Pauls 2003). Records of sea anemone species for Venezuela are scattered in studies of different nature, such as taxonomy (Agudo 1987; den Hartog 1980), biological and ecological interactions (Bastidas \& Bone 1996; Bitter-Soto 1999; Briggs et al. 1996; Henríquez \& Palacios 2008; Losada et al. 1988), feeding behavior (Liñero-Arana \& González 2008), and descriptions of crustacean species engaged in symbiotic associations with sea anemones (Knowlton \& Keller 1985).

The most extensive reference for sea anemones in Venezuela is the monograph of Agudo (1987), which 
includes the records and distribution of 47 species along the main coastal and insular localities (Losada \& Pauls 2003). However, the taxonomic status of some of the species reported by Agudo (1987) has changed through time (e.g. Grajales \& Rodríguez 2014). Therefore, an updated status of the sea anemone diversity for the region is necessary.

In this study we examined specimens of sea anemones sensu lato (i.e. orders Actiniaria, Ceriantharia, Corallimorpharia, and Zoanthidea) sampled during November 2012 in several shallow coastal and coral reefs environments along six locations, four of which are marine reserves in Venezuela (Fig. 1). Additionally, we examined the sea anemone specimens previously deposited in the collection of the Museo Oceanológico Hermano Benigno Román (MOHBR), of the Estación de Investigaciones Marinas at the Fundación La Salle de Ciencias Naturales, in Isla de Margarita (Venezuela). We identified 18 species of Actiniaria, one species of Ceriantharia, one species of Corallimorpharia, and six species of Zoanthidea; we confirmed the identification and updated the current taxonomic status of the sea anemone specimens in the collection of the MOHBR, including those from Agudo (1987) vouchered at the MOHBR. We also provided photographs for these 26 species in the lab or in natural habitats to guide identifications. These species do not represent all species of sea anemones found or reported in Venezuela, but they do represent those that are either more abundant or conspicuous. The major aim of this publication is to inventory the most common anemones in Venezuela and to provide an aid distinguishing these species to facilitate further biological and ecological research requiring species-level resolution.

\section{Results}

List of species of sea anemone found in the sampled localities

We collected and examined 128 specimens belonging to 26 species, 20 genera, 14 families, and four taxonomic orders (Table 1; Appendix 1). Twenty-four of these species have been previously reported for Venezuela; the species Anthopleura pallida Duchassaing \& Michelotti, 1864a, and Telmatactis vernonia (Duchassaing \& Michelotti, 1864b) are reported here for the first time for the country (Table 1).

\section{Systematics}

Order ACTINIARIA Hertwig, 1882

Suborder ENTHEMONAE Rodríguez et al. 2014

Superfamily ACTINIOIDEA Rodríguez et al. 2014

Family ACTINIIDAE Rafinesque, 1815

Actinostella flosculifera (Le Sueur, 1817)

(Fig. 2a)

Actinia flosculifera Le Sueur, 1817

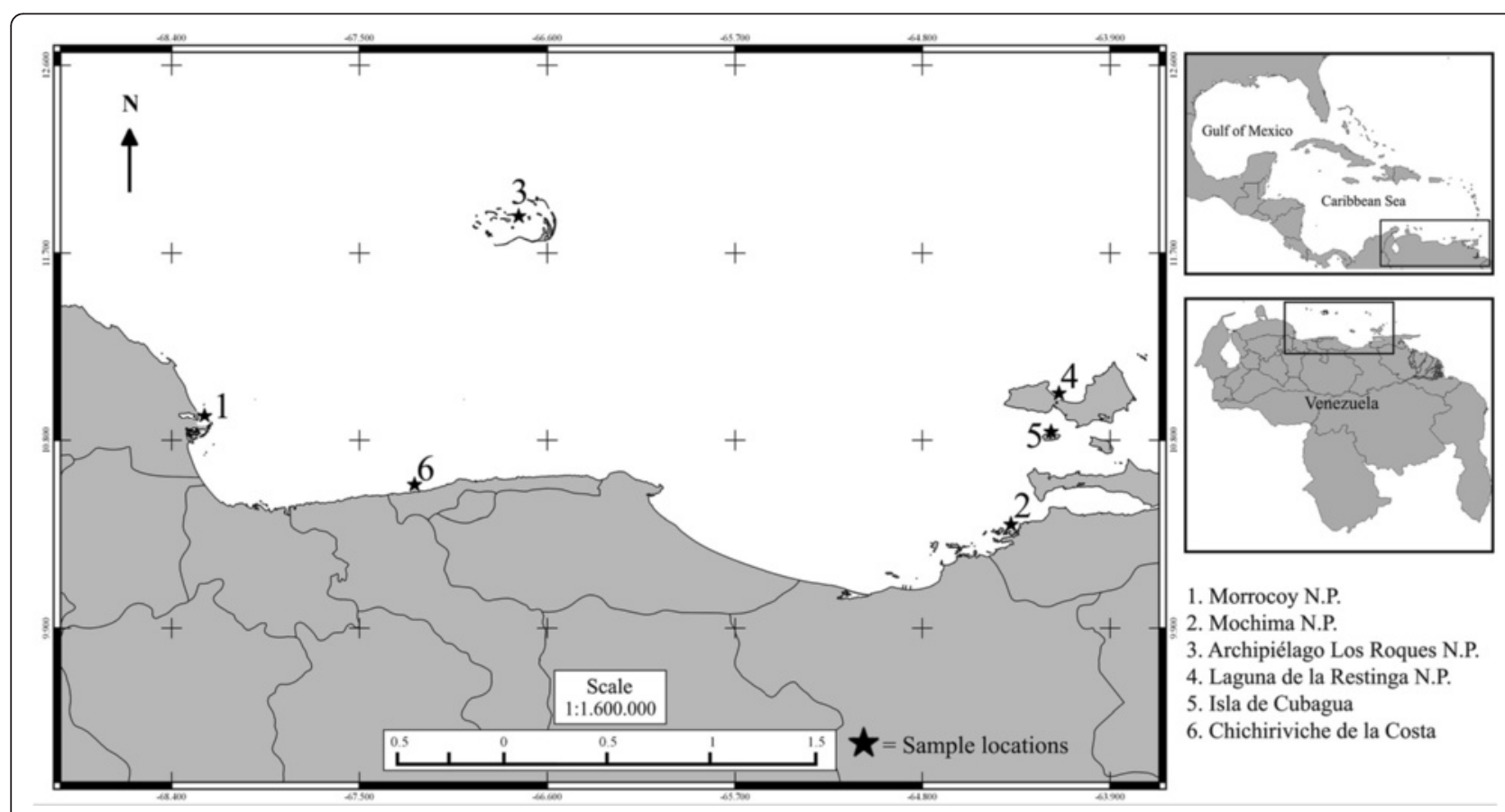

Fig. 1 Map of the coast of Venezuela indicating the localities sampled in this study: (1) Morrocoy National Park, (2) Mochima National Park, (3) Los Roques Archipelago National Park, (4) Laguna de La Restinga National Park, (5) Isla de Cubagua, (6) Chichiriviche de la Costa 
Table 1 Distribution of sea anemones documented along the coast, islands and archipelagos of Venezuela

\begin{tabular}{|c|c|c|c|c|c|c|c|c|c|c|c|c|}
\hline \multirow[b]{2}{*}{ Species } & \multicolumn{4}{|l|}{ West Coast } & \multicolumn{4}{|l|}{ Central Coast } & \multicolumn{4}{|l|}{ East Coast } \\
\hline & $\begin{array}{l}\text { Isla de } \\
\text { Pájaros, } \\
\text { Maracaibo }\end{array}$ & $\begin{array}{l}\text { Morrocoy } \\
\text { National } \\
\text { Park }\end{array}$ & $\begin{array}{l}\text { Isla Goaigoaza, } \\
\text { Puerto Cabello }\end{array}$ & $\begin{array}{l}\text { San Esteban } \\
\text { National Park }\end{array}$ & $\begin{array}{l}\text { Chichiriviche } \\
\text { de la Costa }\end{array}$ & $\begin{array}{l}\text { Playa Azul, } \\
\text { litoral } \\
\text { Central }\end{array}$ & $\begin{array}{l}\text { Balneario } \\
\text { Camuri } \\
\text { Chico }\end{array}$ & $\begin{array}{l}\text { Los } \\
\text { Totumos }\end{array}$ & $\begin{array}{l}\text { Mochima } \\
\text { National } \\
\text { Park }\end{array}$ & Araya & $\begin{array}{l}\text { Playa San Luis, } \\
\text { Cumaná }\end{array}$ & $\begin{array}{l}\text { La Chica, Golfo } \\
\text { de Cariaco }\end{array}$ \\
\hline
\end{tabular}

Order ACTINIARIA

Family Edwardsiidae Andres, 1881

1 Scolanthus

curacaoensis

Family Actiniidae Rafinesque, 1815

2 Actinia bermudensis

3 Actinostella

flosculifera

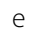

4 Anemonia

sargassensis

Anthopleura cascaia

6 Anthopleura krebsi

Anthopleura pallida

Bunodosoma caissarum?

9 Bunodosoma cangicum?

10 Bunodosoma cavernatum

11 Bunodosoma granuliferum

Bunodosoma kuekenthali?

13 Condylactis gigantea

14 Isoaulactinia stelloides

15 Phymactis sp.? Family Capneidae Gosse, 1860

16 Actinoporus elegans

\begin{tabular}{|c|c|c|c|c|c|c|}
\hline e & e & & & & & \\
\hline a & e & e & e & & e & e \\
\hline \multirow[t]{2}{*}{ e } & e & $a, e$ & e & e & e & \\
\hline & e & & & & & \\
\hline e & e & & e & & e & $\mathrm{e}$ \\
\hline e & e & & & & & e \\
\hline \multirow[t]{2}{*}{ e } & e & & & & e & e \\
\hline & & & & e & & $\mathrm{e}$ \\
\hline e & $a, e$ & e & & e & e & e \\
\hline \multirow[t]{2}{*}{ a } & e & & $*, e$ & e & & $\mathrm{e}$ \\
\hline & e & e & & & & $\mathrm{e}$ \\
\hline
\end{tabular}


Table 1 Distribution of sea anemones documented along the coast, islands and archipelagos of Venezuela (Continued)

Family Phymanthidae Andres, 1883

18 Phymanthus crucifer a, e

Family Stichodactylidae Andres, 1883

19 Stichodactyla a, e helianthus

e, h

Family Aiptasiidae Carlgren, 1924a

20 Bartholomea

$a, c, e, g, *$

Bartholomea

e

werneri

22 Exaiptasia pallida

$a, e,{ }^{*}$

23 Laviactis lucida

Family Aliciidae Duerden, 1895

24 Lebrunia coralligens

25 Lebrunia neglecta a, e, *

Family Boloceroididae Carlgren, 1924b

26 Bunodeopsis

antilliensis

Family Diadumenidae Stephenson, 1920

27 Diadumene lineata

Family Hormathiidae Carlgren, 1932

28 Calliactis tricolor

e

29 Monactis vestita

Family Isophelliidae Stephenson, 1935

30 Telmatactis cricoides

31 Telmatactis

vernonia

Order CERIANTHARIA

Family Arachnanthidae McMurrich, 1910

32 Isarachnanthus nocturnus

Family Cerianthidae

33 Ceriantheopsis

americanus

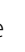

*, e

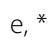

e

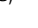

$e^{*}$

a, e

e

a e

*,e e

*, N

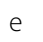

(n)

$x^{2}$

$+\frac{10}{\infty}$ 
Table 1 Distribution of sea anemones documented along the coast, islands and archipelagos of Venezuela (Continued)

34 Ceriantheomorphe e

brasiliensis

35 Pachycerianthus

curacaoensis

Order CORALLIMORPHARIA

Family Corallimorphidae Hertwig, 1882

36 Conynactis

caribbeorum

Family Discosomatidae Duchassaing \& Michelotti, 1864a

37 Discosoma

e

carlgreni

38 Rhodactis osculifera

Order ZOANTHIDEA

Family Sphenopidae Hertwig, 1882

39 Palythoa

caribaeorum

$e, f^{*}$

Palythoa

e

mammillosa?

41 Palythoa grandis

e

42 Palythoa variabilis

Family Zoanthidae

Isaurus

duchassaingi

44 Zoanthus proteus +

45 Zoanthus pulchellus

46 Zoanthus sociatus

47 Zoanthus solanderi

Family Epizoanthidae Delage \& Hirouard, 1901

48 Epizoanthus

cutressi

Family Parazoanthidae Delage \& Hirouard, 1901

49 Parazoanthus

catenularis

50 Parazoanthus

$e^{*}$ * 
Table 1 Distribution of sea anemones documented along the coast, islands and archipelagos of Venezuela (Continued)

52 Parazoanthus swiftii

Localities sampled in the present study in bold. (*) records documented in our surveys, (?) doubtful previous records, ( + ) species currently considered as invalid, (N) new records for Venezuela. Citation of previous records: (a) Specimens of the MOHBR scientific collection (see Appendix 2), (b) den Hartog (1980), (c) Knowlton \& Keller (1985), (d) Riemann-Zürneck (1986), (e) Agudo (1987), (f) Bastidas \& Bone (1996), (g) Bitter-Soto (1999), (h) Henríquez \& Palacios (2008), (i) Liñero-Arana \& González (2008), (j) Carrasquel (2012) 
Table 1 Distribution of sea anemones documented along the coast, islands and archipelagos of Venezuela (Continued)

\begin{tabular}{|c|c|c|c|c|c|c|c|c|c|c|c|c|c|c|c|}
\hline \multirow[b]{2}{*}{ Species } & \multicolumn{9}{|l|}{ East Coast } & \multicolumn{5}{|l|}{$\underline{\text { Oceanic Islands }}$} & \multirow[b]{2}{*}{$\begin{array}{l}\text { Open Sea } \\
\text { Distribution }\end{array}$} \\
\hline & $\begin{array}{l}\text { Laguna de } \\
\text { Chacopata, } \\
\text { Península } \\
\text { de Araya }\end{array}$ & $\begin{array}{l}\text { Isla } \\
\text { Tortuga }\end{array}$ & $\begin{array}{l}\text { Laguna de } \\
\text { Piedras (Isla } \\
\text { de Margarita) }\end{array}$ & $\begin{array}{l}\text { Laguna de } \\
\text { la Restinga } \\
\text { (Isla de } \\
\text { Margarita) }\end{array}$ & $\begin{array}{l}\text { Isla de } \\
\text { Cubagua }\end{array}$ & $\begin{array}{l}\text { Isla de } \\
\text { Coche }\end{array}$ & $\begin{array}{l}\text { Isla Testigo } \\
\text { Grande, Los } \\
\text { Testigos }\end{array}$ & $\begin{array}{l}\text { Isla Iguana, } \\
\text { Los Testigos }\end{array}$ & $\begin{array}{l}\text { Golfo de } \\
\text { Paria }\end{array}$ & $\begin{array}{l}\text { Archipiélago } \\
\text { Los Roques } \\
\text { National Park }\end{array}$ & $\begin{array}{l}\text { Archipiélago } \\
\text { la Orchilla }\end{array}$ & $\begin{array}{l}\text { Isla La } \\
\text { Blanquilla }\end{array}$ & $\begin{array}{l}\text { Isla Los } \\
\text { Hermanos }\end{array}$ & $\begin{array}{l}\text { Isla de } \\
\text { Aves }\end{array}$ & \\
\hline
\end{tabular}

Order ACTINIARIA

Family Edwardsiidae Andres, 1881

1 Scolanthus

e, i

curacaoensis

Family Actiniidae Rafinesque, 1815

2 Actinia bermudensis

3 Actinostella

flosculifera

4 Anemonia

sargassensis

5 Anthopleura cascaia $\dagger$

6 Anthopleura krebsi

7 Anthopleura pallida

8 Bunodosoma caissarum?

9 Bunodosoma cangicum?

10 Bunodosoma cavernatum

11 Bunodosoma granuliferum

12 Bunodosoma

13 Condylactis gigantea

14 Isoaulactinia stelloides

15 Phymactis sp.? Family Capneidae Gosse, 1860

16 Actinoporus elegans

Family Homostichanthidae Carlgren, 1900

17 Homostichanthus duerdeni 
Table 1 Distribution of sea anemones documented along the coast, islands and archipelagos of Venezuela (Continued)

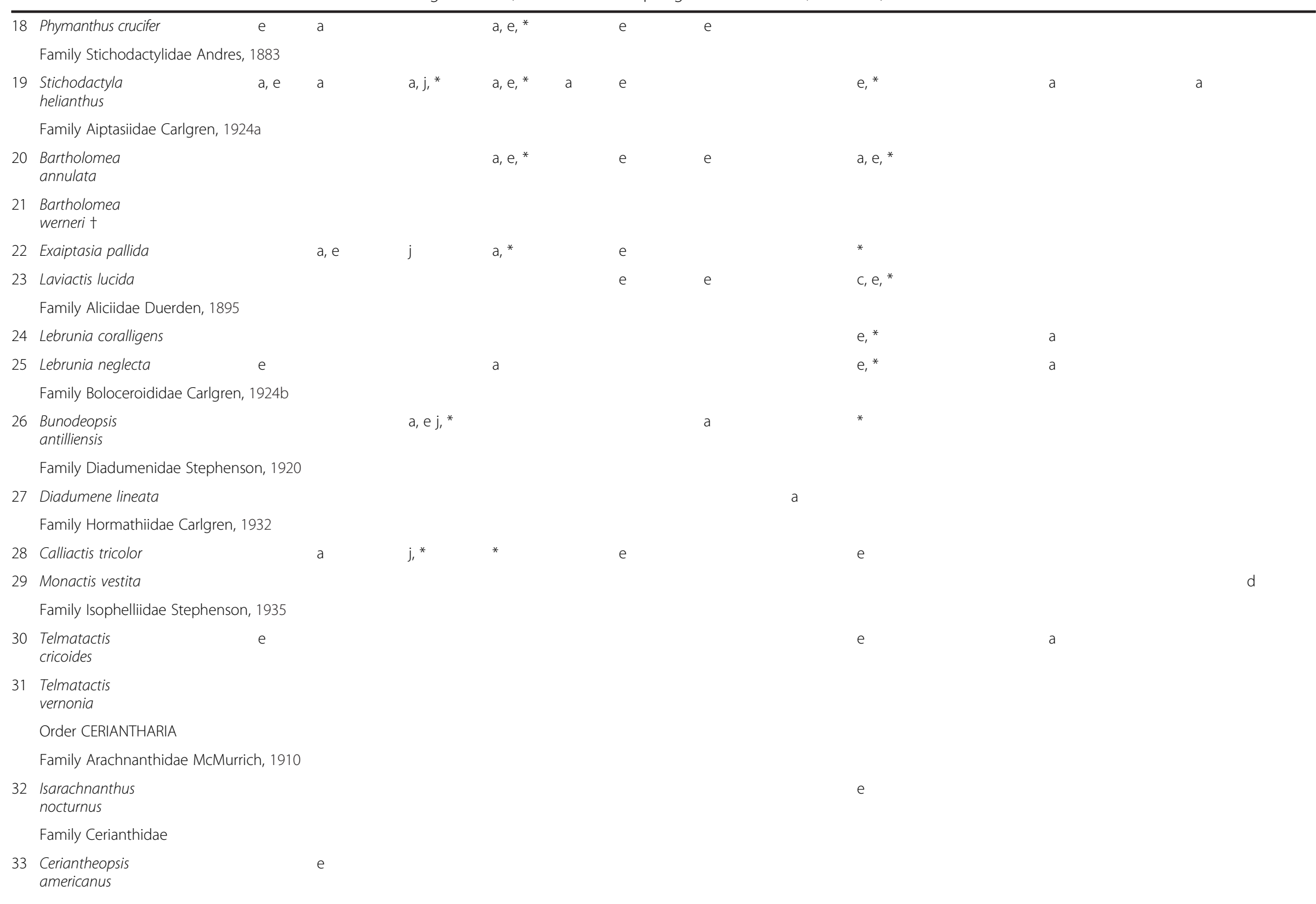


Table 1 Distribution of sea anemones documented along the coast, islands and archipelagos of Venezuela (Continued)

34 Ceriantheomorphe

brasiliensis

35 Pachycerianthus

curacaoensis

Order CORALLIMORPHARIA

Family Corallimorphidae Hertwig, 1882

36 Corynactis

caribbeorum

Family Discosomatidae Duchassaing \& Michelotti, 1864a

37 Discosoma

carlgreni

38 Rhodactis osculifera

Order ZOANTHIDEA

Family Sphenopidae Hertwig, 1882

39 Palythoa e

caribaeorum

40 Palythoa

llosa?

41 Palythoa grandis

42 Palythoa variabilis

Family Zoanthidae

43 Isaurus

duchassaingi

44 Zoanthus proteus $\dagger$

45 Zoanthus pulchellus

46 Zoanthus sociatus

47 Zoanthus solanderi

Family Epizoanthidae Delage \& Hirouard, 1901

48 Epizoanthus cutressi

Family Parazoanthidae Delage \& Hirouard, 1901

49 Parazoanthus

catenularis

50 Parazoanthus

parasiticus 
Table 1 Distribution of sea anemones documented along the coast, islands and archipelagos of Venezuela (Continued)

51 Parazoanthus e e

52 Parazoanthus swiftii 


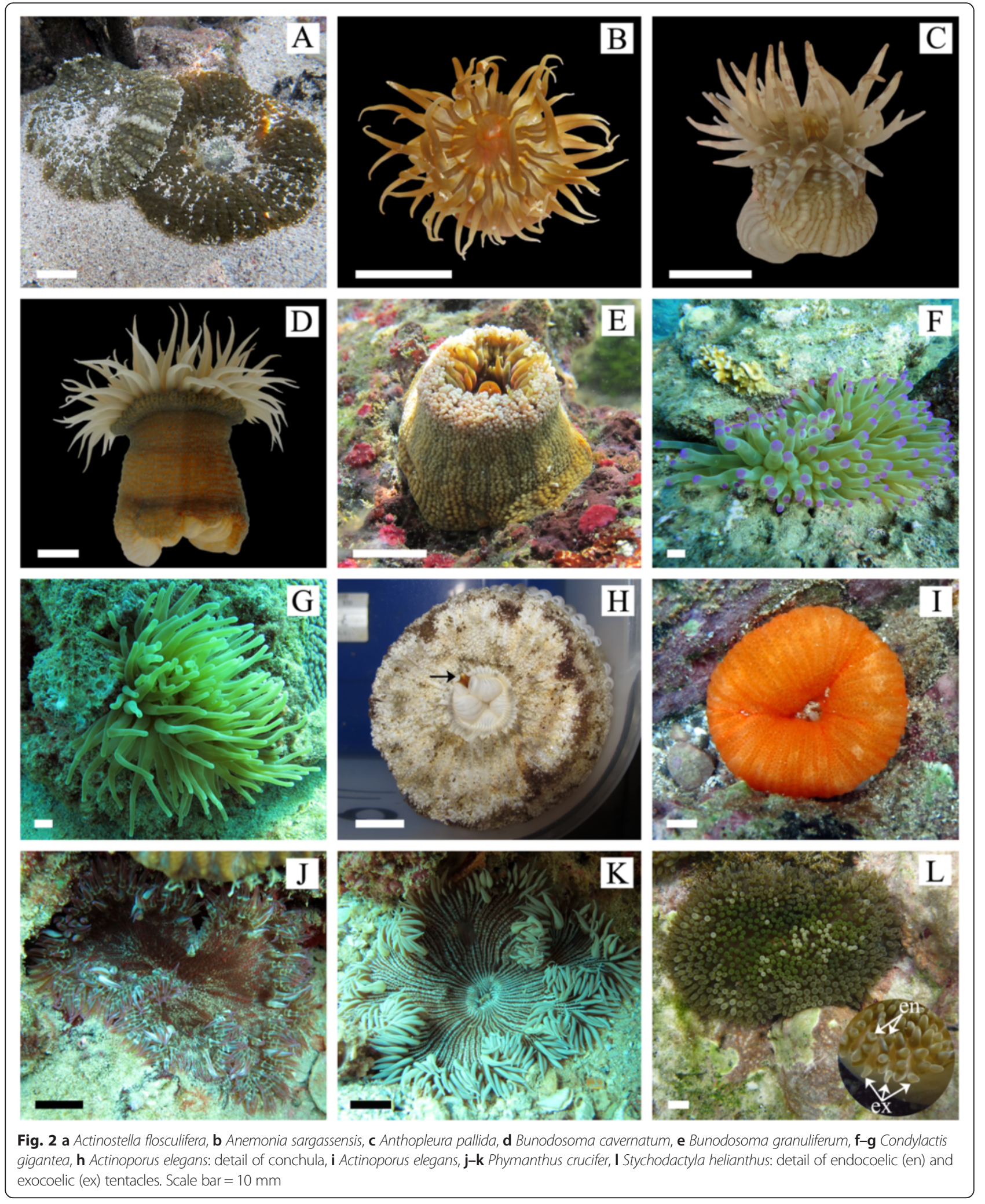

Metridium pretextum: Couthouy in Dana (1846) Actinostella Formosa [sic]: Duchassaing, 1850 Oulactis flosculifera: Milne-Edwards, 1857
Oulactis conquilega: Duchassaing \& Michelotti, 1860 Oulactis Flosculifera [sic]: Duchassaing, 1870 Evactis flosculifera: Andres, 1883 
Oulactis foliosa: Andres, 1883

Oulactis fasciculata: McMurrich, 1889a

Asteractis n. sp.: Duerden, 1897

Asteractis expansa: Duerden in McMurrich, 1898

Cradactis fasciculata: Haddon, 1898

Asteractis flosculifera: Verrill, 1899a

Actinactis flosculifera: Verrill, 1900

Actinostella flosculifera: McMurrich, 1905

Actinostella conchilega: McMurrich, 1905

Phyllactis flosculifera: Stephenson, 1922

Short description Pedal disc well developed, $10-30 \mathrm{~mm}$ in diameter. Column more or less elongate, $20-80 \mathrm{~mm}$ in height, slightly broader than pedal disc, smooth but with small rows of verrucae in its upper part. Pedal disc and column beige or pale orange. Above verrucae and below the margin lies a distinctive collar or marginal ruff formed by 48 rows of small frond-like fused papillae, pale brown or olive-green, and often with dark or pale flashes. Oral disc smooth, short, greyish-white and translucent, but sometimes with white flashes. Oral disc and mouth beige or whitish. Tentacles hexamerously arranged in four cycles (about 48 in specimens examined), inner cycles longer than outer ones, smooth, conical, tapering distally, white and translucent but with small circular white spots in its oral face and along their entire length. For further information on internal anatomy and cnidae see Schlenz \& Belém (1992) and González-Muñoz et al. (2012).

Habitat This species inhabits commonly in seagrass meadows, with the column completely burrowed in the sand with only the marginal ruff, oral disc and tentacles protruding into the water column, often between $0.1-5.0 \mathrm{~m}$.

Distribution Western Atlantic, from Bermuda to Brazil, along the Caribbean Sea and Gulf of Mexico (GonzálezMuñoz et al. 2012, 2013). Also reported in Canary Islands (Ocaña \& den Hartog 2002), and the Gulf of Guinea (Wirtz 2003). Agudo (1987) and Carrasquel (2012) previously reported A. flosculifera (= Phyllactis praetexta) in Venezuela (Table 1) inhabiting coral reefs, seagrass meadows, sandy bottoms, rocky shores, and mangroves.

\section{Anemonia sargassensis Hargitt, 1908}

(Fig. 2b)

Anemonia sargassensis Hargitt, 1908

Anemonia antillensis: Pax, 1924

Anemonia sargassiensis [sic]: Carlgren, 1949

Short description Pedal disc well-developed, 5-20 mm in diameter, reddish or bright to dark-orange. Column cylindrical, short, smooth, reddish to dark-orange. Distal part of column with poorly marked marginal projections forming acrorhagi with holotrichs and basitrichs. Oral disc smooth, 8-25 $\mathrm{mm}$ in diameter, wider than column, reddish to dark-orange but with whitish or yellow radial stripes from the periphery of the mouth to the base of the tentacles; mouth reddish or brightorange. Tentacles irregularly arranged in four or five cycles (about 52-76 in specimens examined), inner cycles longer than outer ones, relatively long, smooth, slender, tapering distally, reddish to dark-orange but with the tips yellowish and sometimes with pink flashes. For further information on internal anatomy and cnidae see Fisher (1976), Carlgren \& Hedgpeth (1952), and González-Muñoz et al. (2013).

Habitat This species inhabits shallow waters of coral reef lagoons, commonly under rocks or coral rubble, or even among colonies of fire-corals, between $0.5-3.0 \mathrm{~m}$, but it has been also reported on floating Sargassum (Carlgren \& Hedgpeth 1952).

Distribution Western Atlantic, from Bermuda and northern coast of the United States to Brazil, along the Caribbean Sea and Gulf of Mexico (González-Muñoz et al. 2012, 2013). Agudo (1987) and Carrasquel (2012) previously reported A. sargassensis in Venezuela (Table 1), inhabiting coral reefs, mangroves, and rocky shores.

\section{Anthopleura pallida Duchassaing \& Michelotti, 1864a}

(Fig. 2c)

Anthopleura pallida Duchassaing \& Michelotti, 1864a

Anthopleura Pallida [sic]: Duchassaing, 1870

Actinioides pallida: Duerden, 1897

Actinoides pallida: Verrill, 1900

Bunodactis stelloides catenulata: Verrill, 1905

Anthopleura catenulata: Cairns et al., 1986

Short description Pedal disc well-developed, 5-10 mm in diameter, grey or whitish. Column cylindrical, stout to elongate, pale to dark-brown. Column with longitudinal rows of verrucae from margin to mid-part; distal end with small and rounded marginal projections forming acrorhagi with holotrichs, basitrichs, microbasic $p$-mastigophores, and spirocysts. Oral disc narrow, smooth, 3-8 $\mathrm{mm}$ in diameter, brownish; mouth slightly clearer than oral disc. Tentacles hexamerously arranged in three or four cycles (about 24-48 in specimens examined), inner cycles longer than outer ones, relatively short, smooth, slender, tapering distally, whitish, translucent, but with white circular spots on its oral face along their entire length, and sometimes with brown flashes. For further information on internal anatomy and cnidae see Daly \& den Hartog (2004), and González-Muñoz et al. (2013). 
Habitat This species lives commonly attached to coral rubble on sandy shores (González-Muñoz et al. 2013), between $0.5-1.5 \mathrm{~m}$, with grains of sand adhered to the verrucae.

Distribution Western Atlantic, from Bermuda to the Caribbean Sea and Gulf of Mexico (Daly \& den Hartog 2004; González-Muñoz et al. 2012, 2013); this is the first record for Venezuela found in Boca Seca, Morrocoy National Park (Table 1).

\section{Bunodosoma cavernatum (Bosc, 1802) \\ (Fig. 2d) \\ Actinia cavernata Bosc, 1802 \\ Urticina cavernata: Duchassaing, 1850 \\ Bunodes cavernata: Verrill, 1864 \\ Phymactis cavernata: Andres, 1883 \\ Bunodosoma cavernata: Verrill, 1899b \\ Anthopleura cavernata: Cary, 1906 \\ Bunodosma cavernata: Daly, 2003}

Short description Pedal disc well-developed, 12-20 mm in diameter. Column cylindrical, densely covered with longitudinal rows of rounded vesicles from the margin to limbus. Pedal disc and column commonly beige or brown-reddish. Distal end of column with small and rounded marginal projections forming acrorhagi with holotrichs and basitrichs. Oral disc wide, smooth, $20-40 \mathrm{~mm}$ in diameter. Oral disc and mouth brown-yellowish, brown-reddish or pale brown. Tentacles hexamerously arranged in five cycles (about 96 in specimens examined), inner cycles longer than outer ones, moderately long, smooth, conical, tapering distally, white or pale-orange. For further information on internal anatomy and cnidae see Carlgren (1952), Carlgren \& Hedgpeth (1952), and González-Muñoz et al. (2013).

Habitat This species lives attached to rocks or coral rubble, in shallow waters between $0.5-7.0 \mathrm{~m}$.

Distribution Western Atlantic, from the northern coast of the United States to the Caribbean Sea and Gulf of Mexico (Carlgren \& Hedgpeth 1952; González-Muñoz et al. 2012, 2013), and in the Caroline Islands, Micronesia (Bosc 1802). Agudo (1987) previously reported Bunodosoma cavernatum $(=$ B. cavernata) in Venezuela (Table 1$)$, inhabiting in coral reefs and mangroves.

\section{Bunodosoma granuliferum (Le Sueur, 1817)}

(Fig. 2e)

Actinia granulifera Le Sueur, 1817

Urticina Lessoni [sic]: Duchassaing, 1850

Oulactis granulifera: Milne-Edwards, 1857

Urticina granulifera: Duchassaing \& Michelotti, 1860
Cereus Lessoni [sic]: Duchassaing \& Michelotti, 1860

Anthopleura granulifera: Duchassaing \& Michelotti, $1864 \mathrm{a}$

Anthopleura Granulifera [sic]: Duchassaing, 1870

Aulactinia granulifera: Andres, 1883

Bunodes teniathus: McMurrich, 1889b

Bunodes taeniatus: Carlgren, 1895

Bunodes granulifera: Duerden, 1897

Bunodosoma granulifera: Verrill, 1899a

Bunodosoma granuliferum: Pax, 1910

Phymactis granulifera: Stephenson, 1922

Short description Pedal disc well-developed, 7-40 mm in diameter, brownish with bright-orange flashes. Column cylindrical, densely covered with longitudinal rows of rounded vesicles arranged in 24 alternated dark and light bands (dark bands with about five rows of vesicles, light ones with about three). Distal end of column with small and rounded marginal projections forming acrorhagi with holotrichs and basitrichs. Oral disc wide, smooth, 20-50 $\mathrm{mm}$ in diameter, olive-green, reddish-brown, dark-red or dark-green; mouth dark-red or yellowish. Tentacles hexamerously arranged in five cycles (about 96 in specimens examined), inner cycles longer than outer ones, moderately long, smooth, conical, tapering distally, olive-green, but with yellowish circular spots on the oral face along its entire length and sometimes with pink or dark-red flashes. For further information on internal anatomy and cnidae see González-Muñoz et al. (2012).

Habitat This species lives attached to rocks, commonly in shallow waters among rocky patches and seagrasses meadows, between $0.5-6.0 \mathrm{~m}$.

Distribution Western Atlantic, from Bermuda to Barbados, along the Caribbean Sea (González-Muñoz et al. 2012). This species has previously been reported by Agudo (1987) and Carrasquel (2012) for Venezuela (Table 1), inhabiting coral reefs, mangroves, and rocky bottoms.

\section{Condylactis gigantea (Weinland, 1860)}

(Fig. 2f-g)

Anthea gigantea Weinland, 1860

Condylactis passiflora: Duchassaing \& Michelotti, 1864a

Condylactis Passiflora [sic]: Duchassaing, 1870

Bunodes passiflora: Andres, 1883

Ilyanthopsis longifilis: Hertwig, 1888

Condylactis gigantea: Verrill, 1905

Short description Pedal disc well-developed, 20-85 mm in diameter. Column cylindrical, smooth, slightly wider 
than pedal disc. Pedal disc and column scarlet or bright to pale orange. Oral disc wide, smooth, $25-100 \mathrm{~mm}$ in diameter; oral disc and mouth yellowish to pale orange with green flashes, or pale green. Tentacles hexamerously arranged in five cycles (about 96 in specimens examined), inner cycles longer than outer ones, long, cylindrical, smooth but striated in appearance, white, greenish or pale brown in color, with tips slightly swollen and blunt, mainly bright green or pink, but sometimes white, bluish or purple. Two color morphs are commonly recognized for this species regarding the color of its tentacles tips: one with pink tips (Fig. 2f), and another one with bright-green tips (Fig. 2g). For further information on internal anatomy and cnidae see Carlgren (1952), and González-Muñoz et al. (2012).

Habitat This species inhabit shallow waters, inside crevices formed by coral rocks and coral rubble, and is also commonly observed among seagrass meadows and mangroves zones; often between $0.5-30.0 \mathrm{~m}$, but has been reported down to $40 \mathrm{~m}$ (Agudo 1987).

Distribution Western Atlantic, from Bermuda to Brazil, along the Caribbean Sea and Gulf of Mexico (GonzálezMuñoz et al. 2012, 2013). Agudo (1987) previously reported C. gigantea in Venezuela (Table 1), inhabiting coral reefs, seagrass meadows, sandy bottoms, mangroves, and rocky shores.

Family CAPNEIDAE Gosse, 1860

Actinoporus elegans Duchassaing, 1850

(Fig. 2h-i)

Actinoporus elegans Duchassaing, 1850

Actinoporus Elegans [sic]: Duchassaing, 1870

Aureliana elegans: Andres, 1883

Short description Pedal disc well-developed, 35-42 mm in diameter. Column cylindrical, elongate but sometimes funnel-shape, $60-100 \mathrm{~mm}$ in length and 45-60 in diameter, smooth but with longitudinal rows of vesicles in its distal part. Pedal disc and column whitish or beige, vesicles grey. Central part of oral disc narrow and smooth; mouth often white and with conchula (Fig. 2h). Tentacles small, vesicle-like, arranged in double radial rows covering almost the entire oral disc, located on endocoelic and exocoelic spaces. Three color morphs regarding tentacles were observed in Venezuela: white tentacles with scattered brown dots (Fig. 2h), white tentacles with pale pink and purple flashes, and tentacles and oral disc completely bright-orange (Fig. 2i). For further information on internal anatomy and cnidae see Corrêa (1973) and González-Muñoz et al. (2013).
Habitat This species inhabits sandy patches, with the pedal disc strongly attached to burrowed rocks, but with the column completely buried in the sand and only the oral disc and tentacles protruding into the water column, often between 1-2 m.

Distribution Western Atlantic, in the Caribbean Sea and Gulf of Mexico to the northern coast of Brazil (Corrêa 1973; González-Muñoz et al. 2013), but also reported in Cape Verde Islands (Wirtz 2009). Agudo (1987) previously reported A. elegans in Venezuela (Table 1), inhabiting sandy bottoms.

Family PHYMANTHIDAE Andres, 1883

Phymanthus crucifer (Le Sueur, 1817)

(Fig. 2j-k)

Actinia crucifera Le Sueur, 1817

Cereus crucifer: Duchassaing \& Michelotti, 1864a

Cereus Crucifer [sic]: Duchassaing, 1870

Phymanthus cruciferus: Andres, 1883

Ragactis cruciata: Andres, 1883

Phymanthus crucifer: McMurrich, 1889a

Epicystis crucifera: Verrill, 1898

Epicystis osculifera: Verrill, 1900

Phymantes crucifer: Cutress \& Cutress, 1976

Phimanthus crucifer: Zamponi, 1981

Epicystis crucifer: Cairns et al., 1986

Short description Pedal disc well-developed, $10-40 \mathrm{~mm}$ in diameter, bright pink or orange. Column cylindrical to plate-like, pinkish or orange in the proximal end and fading into whitish distally, with a flame-like staining pattern; smooth but with longitudinal rows of pink verrucae in its distal part. Oral disc wide, 40$100 \mathrm{~mm}$ in diameter, rough, variable in color, often brown with reddish spots, olive-green with darkbrown and white spots, grey with green spots, or white with dark-brown radial stripes from mouth to the base of the marginal tentacles; mouth olive-green, pale-brown, grey or purple. Two types of tentacles: marginal and discal. Marginal tentacles short, conical, tapering distally, numerous (about 360 in specimens examined), with lateral protuberances in the oral face, or smooth, white with longitudinal light brown stripes. Discal tentacles reduced, vesicle-like, arranged in radial rows on the oral disc. Commonly three morphotypes have been recognized for $P$. crucifer regarding the presence/absence (or an intermediate state) of lateral protuberances on the oral face of the marginal tentacles (the three morphotypes were observed in Venezuela). However, recent morphological and genetic analyses suggest that the three morphotypes should be considered as a single species (González- 
Muñoz et al. 2015). For further information on internal anatomy and cnidae see Carlgren (1952), and González-Muñoz et al. (2012).

Habitat This species lives attached to rocks and coral rubble, with the column burrowed in the sand and only the oral disc protruding into the water column, between $0.5-20.0 \mathrm{~m}$.

Distribution Western Atlantic, along the Caribbean Sea and the Gulf of Mexico (Carlgren 1952; GonzálezMuñoz et al. 2012, 2013). Agudo (1987) previously reported Phymanthus crucifer in Venezuela (Table 1), inhabiting coral reefs, seagrass meadows, sandy bottoms, and mangroves.

Family STICHODACTYLIDAE Andres, 1883

Stichodactyla helianthus (Ellis, 1768)

(Fig. 2l)

Actinia helianthus Ellis, 1768

Actinia Helianthus [sic]: Ellis \& Solander, 1786

Actinia Anemone [sic]: Ellis \& Solander, 1786

Discosoma anemone: Duchassaing, 1850

Discosoma helianthus: Milne-Edwards, 1857

Discosoma Helianthus [sic]: Duchassaing \& Michelotti, 1864a

Discosoma Anemone [sic]: McMurrich, 1898

Stoichactis anemone: Haddon, 1898

Stoichactis helianthus: Carlgren, 1900

Stichodactyla helianthus: Dunn, 1981

Stoichactis Helianthus [sic]: Zamponi \& Pérez, 1996

Short description Pedal disc well-developed, 35-75 mm in diameter. Column short, diabolo-shaped, smooth but with longitudinal rows of small verrucae in its distal part. Pedal disc and column beige, verrucae greenish or light-brown. Oral disc $50-250 \mathrm{~mm}$ in diameter, flat to domed, beige or greenish; mouth beige. Tentacles short, digitiform, blunt, arranged in single radial endocoelic rows covering almost the entire oral disc; each endocoelic row with dozens of tentacles but only one tentacle at the margin per exocoelic row (Fig. 2l). Tentacles light brown near their bases and bright-green or with yellowish shades at tips. For further information on internal anatomy and cnidae see Dunn (1981), and González-Muñoz et al. (2012, 2013).

Habitat This species lives strongly attached to rocks and coral rubble among sandy and seagrass meadows, often between $0.5-12.0 \mathrm{~m}$.

Distribution Western Atlantic, from Bermuda to Brazil, along the Caribbean Sea and Gulf of Mexico (González-Muñoz et al. 2012, 2013). This species has previously been reported in Venezuela by Agudo (1987) and Carrasquel (2012) (Table 1), inhabiting coral reefs, seagrass meadows, and mangroves.

Superfamily METRIDIOIDEA Carlgren, 1893

Family AIPTASIIDAE Carlgren, 1924a

Bartholomea annulata (Le Sueur, 1817)

(Fig. 3a)

Actinia annulata Le Sueur, 1817

Actinia solifera: Le Sueur, 1817

Paractis solifera: Milne-Edwards, 1857

Dysactis annulata: Milne-Edwards, 1857

Bartholomea solifera: Duchassaing \& Michelotti, 1864a

Bartholomea Solifera [sic]: Duchassaing, 1870

Aiptasia solifera: Andres, 1883

Aiptasia annulata: Andres, 1883

Aiptasia annulata solifera: Verrill, 1907

Bartholomea annulata: Stephenson, 1920

Aiptasia arrulata: Atoda, 1954

Batholomea annulata [sic]: Chen et al., 2008

Short description Pedal disc well-developed, 10-25 mm in diameter. Column cylindrical to elongate, divided in capitulum and scapus. Capitulum thin, smooth, light to dark-brown, translucent, with white and yellow scattered spots; scapus robust, smooth but corrugate in appearance when contracted, light brown. Mid-part of scapus with four to five rows of cinclides. Oral disc $30-45 \mathrm{~mm}$ in diameter, smooth, flat, brownish, translucent, with small white and yellow dots, and sometimes with triangular spots at the base of some tentacles; mouth beige. Tentacles hexamerously arranged in up to five cycles (about 48 to 96 in specimens examined), long, slender, inner cycles longer than outer ones, tapering distally, brown but translucent, with a distinct pattern of white spiral bands giving the appearance of a corkscrew. Acontia can be protruding to the water column through the cinclides or the mouth. For further information on internal anatomy and cnidae see Carlgren (1952), Carlgren \& Hedgpeth (1952), González-Muñoz et al. (2012), and Rodríguez et al. (2014).

Habitat This species lives in shallow waters inside crevices of rocks and coral rubble, with only its tentacles above the substrate. It is often observed in caves and crevices at the interface between hard and sandy substratum, commonly between $0.5-15.0 \mathrm{~m}$, but also observed down to $40 \mathrm{~m}$.

Distribution Western Atlantic, from Bermuda to Barbados, along the Caribbean Sea and Gulf of Mexico (González-Muñoz et al. 2012, 2013). Agudo (1987) previously reported B. annulata in Venezuela (Table 1), 


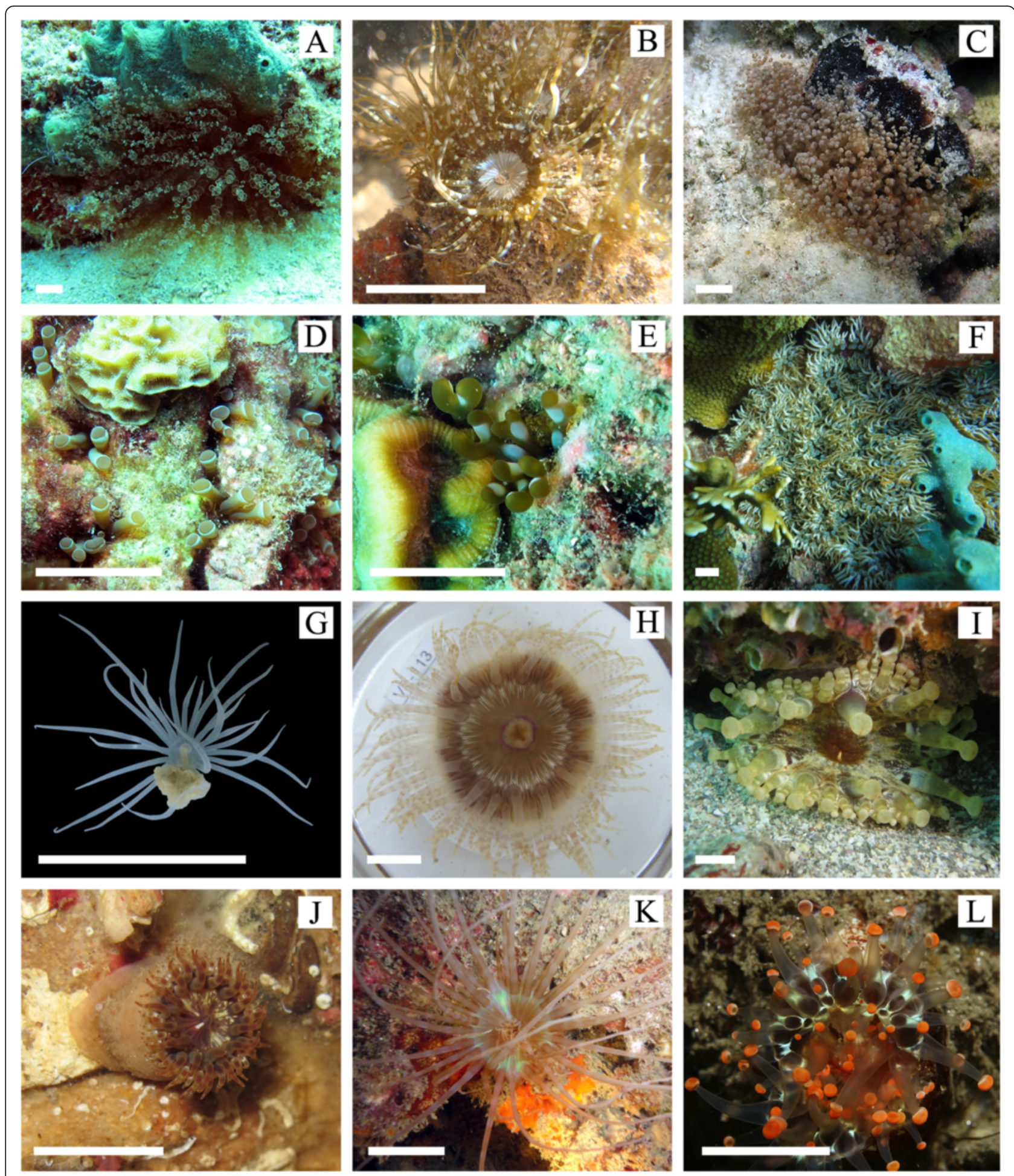

Fig. 3 a Bartholomea annulata, b Exaiptasia pallida, c Laviactis lucida, d-e Lebrunia coralligens, $\mathbf{f}$ Lebrunia neglecta, $\mathbf{g}$ Bunodeopsis antilliensis, $\mathbf{h}$ Calliactis tricolor, $\mathbf{i}$ Telmatactis cricoides, $\mathbf{j}$ Telmatactis vernonia, $\mathbf{k}$ Isarachnanthus nocturnus, I Corynactis caribbeorum. Scale bar $=10 \mathrm{~mm}$ 
inhabiting coral reefs, seagrass meadows, mangroves, and rocky shores.

\section{Exaiptasia pallida (Agassiz in Verrill, 1864)}

(Fig. 3b)

Actinia diaphana Rapp, 1829

Cribina diaphana: Deshayes \& Milne-Edwards, 1840

Actinia elongata: Delle Chiaje, 1841

Adamsia diaphana: Milne-Edwards, 1857

Dysactis pallida: Agassiz in Verrill, 1864

Bartholomea tagetes: Duchassaing \& Michelotti, 1864a

Bartholomea inula: Duchassaing \& Michelotti, 1864a

Dysactis mimosa: Duchassaing \& Michelotti, 1864a

Dysactis minuta: Verrill, 1867

Paranthea minuta: Verrill, 1868

Paranthea pallida: Verrill, 1868

Disactis mimosa [sic]: Duchassaing, 1870

Aiptasia saxicola: Andres, 1881

Aiptasia diaphana: Andres, 1883

Aiptasia Agassizii [sic]: Andres, 1883

Aiptasia inula: Andres, 1883

Aiptasia minuta: Andres, 1883

Aiptasia mimosa: Andres, 1883

Aiptasia tagetes: Andres, 1883

Aiptasia pallida: McMurrich, 1887

Aiptasia leiodactyla: Pax, 1910

Aiptasia insignis: Carlgren, 1941

Aiptasioides pallida: Stephenson, 1918

Aiptasiomorpha diaphana: Stephenson, 1920

Aiptasiomorpha leiodactyla: Stephenson, 1920

Aiptasia pulchella: Carlgren, 1943

Aiptasia califórnica: Carlgren, 1952

Aiptasiomorpha minuta: Uchida \& Soyama, 2001

Aipstasia pulchella [sic]: Reimer et al., 2007

Exaiptasia pallida: Grajales \& Rodríguez, 2014

Short description Pedal disc well-developed, 3-10 mm in diameter. Column cylindrical to elongate, only distinctly divisible into capitulum and scapus when contracted. Capitulum smooth, beige to dark brown, translucent; scapus smooth but corrugate in appearance when contracted, beige to dark brown. Column with two to three rows of cinclides in mid-scapus. Oral disc 5-15 $\mathrm{mm}$ in diameter, smooth, flat, brownish with white circular spots, or brownish, translucent, with small white, yellow, and bluish scattered dots; mouth brownish and sometimes surrounded by whitish spots. White acontia can be observed protruding through mouth or cinclides. Tentacles hexamerously arranged in four cycles (about 48 in specimens examined), long, smooth, slender, inner cycles longer than outer ones, tapering distally, brown, translucent, with white or bluish scattered dots along its entire length. For further information on internal anatomy and cnidae see Carlgren (1952), Carlgren \& Hedgpeth (1952), González-Muñoz et al. (2012), and Grajales \& Rodríguez (2014).

Habitat This species lives attached to rocks, coral rubble, submerged lumber, or mangrove roots, often between $0.5-22.0 \mathrm{~m}$. It is commonly observed forming aggregations as a result of asexual reproduction by pedal laceration (González-Muñoz et al. 2012).

Distribution Worldwide distribution along the northwestern Atlantic coast, from Bermuda to Brazil, the Caribbean Sea and Gulf of Mexico, the Galapagos Islands, Australia, the Mediterranean Sea and the western coast of Africa, Japan and Hawaii, and Saint Helena Island (Grajales \& Rodríguez 2014). Exaiptasia pallida (= Aiptasia pallida) has previously been registered in Venezuela (Agudo 1987; Carrasquel 2012) (Table 1), inhabiting the roots of mangroves.

\author{
Laviactis lucida (Duchassaing \& Michelotti, 1860) \\ (Fig. 3c) \\ Capnea lucida Duchassaing \& Michelotti, 1860 \\ Heteractis lucida: Duchassaing \& Michelotti, 1864a \\ Heteractis Lucida [sic]: Duchassaing, 1870 \\ Ragactis lucida: Andres, 1883 \\ Aiptasia lucida: Duerden, 1897 \\ Bartholomea pseudoheteractis: Watzl, 1922 \\ Bartholomea lucida: Carlgren, 1949 \\ Laviactis lucida: Grajales \& Rodríguez, 2014
}

Short description Pedal disc well-developed, 15-25 mm in diameter. Column cylindrical to elongate, divided in capitulum and scapus. Capitulum smooth, beige to dark brown, translucent, with light-brown to white dots; scapus smooth but corrugate in appearance when contracted, beige. Column with up to five rows of cinclides in midscapus. Oral disc 15-30 mm in diameter, smooth, flat, brownish, translucent, with small yellow dots around the mouth. Tentacles hexamerously arranged in up to five cycles (about 48 to 96 in specimens examined), inner cycles longer than outer ones, all long, slender, tapering distally, brownish, translucent, with numerous white or grey spherical hollow vesicles irregularly arranged, giving the appearance of knobby tentacles; vesicles containing batteries of cnidae. White acontia can be observed protruding through mouth or cinclides. For further information on internal anatomy and cnidae see González-Muñoz et al. (2012), and Grajales \& Rodríguez (2014).

Habitat This species lives attached to hard substratum, inside crevices or holes of rocks or coral rubble with only the tentacles protruding into the water column, often between $0.5-10.0 \mathrm{~m}$. 
Distribution Western Atlantic, from Bahamas to Barbados, along the Caribbean Sea and Gulf of Mexico (GonzálezMuñoz et al. 2012, 2013; Grajales \& Rodríguez 2014). Agudo (1987) previously reported L. lucida (= Bartholomea lucida) in Venezuela (Table 1), inhabiting coral reefs.

Family ALICIIDAE Duerden, 1895

Lebrunia coralligens (Wilson, 1890)

(Fig. 3d-e)

Hoplophoria coralligens Wilson, 1890

Lebrunea coralligens: Duerden, 1898a

Lebrunia coralligens: Stephenson, 1922

Short description Pedal disc well-developed, 3-6 mm in diameter. Column cylindrical, short, smooth, light brown, often with 4-6 branched outgrowths distally (pseudotentacles), which ends are as globular-shaped vesicles. Specimens with two morphs regard of pseudotentacles are often observed: the first one with branched ends bluish with a grey or brown circle in the center (Fig. 3d), and the second one with ends bifurcated, brown with grey or white spots (Fig. 3e). Oral disc 3-5 $\mathrm{mm}$ in diameter, smooth, beige and translucent. Tentacles hexamerously arranged in four cycles (about 48 in number), inner cycles longer than outer ones, smooth but striated in appearance, moderately long, slender, tapering distally, greyish or brownish, translucent, with whitish or yellowish tips and scattered bluish dots along its length. For further information on internal anatomy and cnidae see Crowther (2013) and González-Muñoz et al. (2013).

Habitat This species lives attached to hard substratum, inside crevices or holes of rocks or live coral, and commonly observed with only the pseudotentacles protruding into the water column; often between $0.5-6.0 \mathrm{~m}$.

Distribution Western Atlantic, from Bahamas to Brazil and along the Caribbean Sea and Gulf of Mexico (GonzálezMuñoz et al. 2012, 2013). Lebrunia coralligens has previously been registered in Venezuela by Agudo (1987) (Table 1), inhabiting coral reefs.

\footnotetext{
Lebrunia neglecta Duchassaing \& Michelotti, 1860 (Fig. 3f)

Oulactis Danae [sic] Duchassaing \& Michelotti, 1860 Lebrunia neglecta: Duchassaing \& Michelotti, 1860 Actinodactylus neglectus: Duchassaing \& Michelotti, 1860 Rhodactis Danae [sic]: Duchassaing \& Michelotti, 1864a Lebrunea neglecta: Duchassaing \& Michelotti, 1864a Rodactis Dance [sic]: Duchassaing, 1870 Actinodactylus Neglectus [sic]: Duchassaing, 1870
}

Taractea Danae [sic]: Andres, 1883

Stauractis incerta: Andres, 1883

Hoplophoria coralligens: Wilson, 1890

Rhodactis Dance [sic]: Haddon, 1898

Lebrunia Danæe [sic]: Verrill, 1899a

Lebrunia Danae [sic]: Verrill, 1907

Aiptasia sp.: Verrill, 1907

Lebrunia danae: Pax, 1910

Cradactis variabilis: Hargitt, 1911

Lebrunia dance: Weill, 1934

Lubrunia danae: Hedgpeth, 1954

Lebrunea danae: Zeiller, 1974

Labrunia danae: Hanlon et al., 1983

Short description Pedal disc well-developed, $10-50 \mathrm{~mm}$ in diameter. Column cylindrical, smooth, beige, with often 4-6 branched beige to dark-brown pseudotentacles distally, with extremely ramified forked tips; small white or grey vesicles among ramifications. Oral disc 10$25 \mathrm{~mm}$ in diameter, smooth, flat, beige and translucent. Tentacles hexamerously arranged in four cycles (about 48 in specimens examined), inner cycles longer than outer ones, all smooth but striated in appearance, moderately long, slender, tapering distally, beige but whitish toward tips and with small scattered white dots. For further information on internal anatomy and cnidae see González-Muñoz et al. (2012) (as L. danae) and Crowther (2013).

Habitat This species lives attached to hard substratum, inside holes or crevices among live corals and rocks, and commonly observed during day with only the pseudotentacles protruding into the water column; often between $0.5-12.0 \mathrm{~m}$, but it has been reported down to $60 \mathrm{~m}$ depth (Ocaña et al. 2007).

Distribution Western Atlantic, from Bermuda to Brazil, and along the Caribbean Sea and Gulf of Mexico (González-Muñoz et al. 2012, 2013). Agudo (1987) previously registered $L$. neglecta $(=L$. danae) in Venezuela (Table 1), inhabiting coral reefs, mangroves, and rocky shores.

Family BOLOCEROIDIDAE Carlgren, 1924b

Bunodeopsis antilliensis Duerden, 1897

(Fig. 3g)

Bunodeopsis antilliensis Duerden, 1897

Bunodeopsis n. sp.: Duerden, 1898a

Bunodeopsis Antilliensis [sic]: Haddon, 1898

Viatrix globulifera: Verrill, 1899a

Bunodeopsis globulifera: Verrill, 1900 
Short description Pedal disc well-developed, 4-13 mm in diameter, greyish or olive-green, translucent. Column short, $5-10 \mathrm{~mm}$ in diameter and $4-10 \mathrm{~mm}$ in height, divided in capitulum and scapus. Capitulum short, narrower than oral disc, smooth, whitish and translucent; scapus wider than oral disc, covered with longitudinal rows of globular vesicles, white to greenish-brown. Oral disc 4-7 $\mathrm{mm}$ in diameter, whitish and translucent. Tentacles irregularly arranged in three to four cycles (about 16-46 in specimens examined), inner cycles longer than outer ones, all long, smooth, tapering distally, whitish and translucent, with white dots scattered along their entire length. The tentacles are deciduous and can be completely detached by contraction of a sphincter in the base of each tentacle. For further information on internal anatomy and cnidae see Duerden (1897) and González-Muñoz et al. (2012).

Habitat This species lives attached to seagrass leaves of Syringodium filiforme or Thalassia testudinum, between $0.5-6.0 \mathrm{~m}$.

Distribution Western Atlantic, from Bermuda to Curaçao, and along the Caribbean Sea and Gulf of Mexico (González-Muñoz et al. 2012, 2013). Bunodeopsis antilliensis $(=B$. globulifera $)$ has been reported in Venezuela by Agudo (1987) and Carrasquel (2012) (Table 1), inhabiting seagrass meadows and mangroves.

Family HORMATHIIDAE Carlgren, 1932

\section{Calliactis tricolor (Le Sueur, 1817)}

(Fig. 3h)

Actinia tricolor Le Sueur, 1817

Actinia bicolor: Le Sueur, 1817

Cereus bicolor: Milne-Edwards, 1857

Adamsia tricolor: Milne-Edwards, 1857

Adamsia Egletes [sic]: Duchassaing \& Michelotti, 1864a

Adamsia egletes: Duchassaing \& Michelotti, 1866

Calliactis bicolor: Verrill, 1869

Adamsia sol: McMurrich, 1893

Adamsia bicolor: Andres, 1883

Adamsia tricolor: Andres, 1883

Calliactis tricolor: Haddon, 1898

Short description Pedal disc well-developed, 10$30 \mathrm{~mm}$ in diameter, pale-orange, translucent. Column cylindrical, $12-32 \mathrm{~mm}$ height and $16-40 \mathrm{~mm}$ diameter, trumped-shaped when expanded and domeshaped when contracted, divided into capitulum and scapus. Capitulum short, smooth, pale-brown to yellowish, translucent; scapus robust, wrinkled-texture, bright to dark-orange, often with white flashes proximally, and with one or two rows of dark-red or brown cinclides proximally. Oral disc slightly wider than column, smooth, pale-brown and translucent, often with radial white stripes that sometimes forming a white ring around the peristome; mouth bright-yellow, often surrounded by a purple ring. Tentacles hexamerously arranged in up to five cycles (about 48-96 in specimens examined), inner cycles longer than outer ones, smooth, slender, moderately short, tapering distally, whitish, greyish or pale-brown, with longitudinal rows of white dots along its entire length. White or brightorange acontia can be protruding through mouth or cinclides. For further information on internal anatomy and cnidae see Gusmão (2010), and González-Muñoz et al. (2013).

Habitat This species is commonly found attached to shells of living hermit crabs, between $0.5-40.0 \mathrm{~m}$.

Distribution Western Atlantic, from the northern coast of the United States to the northern coast of Brazil, and along the Caribbean Sea and Gulf of Mexico (Carlgren \& Hedgpeth 1952; González-Muñoz et al. 2012, 2013; Zamponi et al. 1998). Agudo (1987) and Carrasquel (2012) previously registered C. tricolor in Venezuela (Table 1), inhabiting coral reefs and mangroves.

Family ISOPHELLIIDAE Stephenson, 1935

Telmatactis cricoides (Duchassaing, 1850)

(Fig. 3i)

Entacmaea cricoides Duchassaing, 1850

Dysactis cricoides: Duchassaing \& Michelotti, 1860

Paractis clavata: Duchassaing \& Michelotti, 1860

Capnea cricoides: Duchassaing \& Michelotti, 1864a

Capnea clavata: Duchassaing \& Michelotti, 1864a

Phellia Americana [sic]: Verrill, 1868

Phellia cricoides: Verrill, 1869

Phellia Duchassaingi [sic]: Andres, 1883

Phellia clavata: Duerden, 1898a

Phellia rufa: Verrill, 1901

Euphellia cinclidifera: Pax, 1908

Telmatactis Valle-Flori [sic]: Gravier, 1916

Phellia pseudoroseni: Pax, 1924

Telmatactis valle-flori [sic]: Carlgren, 1941

Telmatactis americana: Carlgren, 1949

Telmatactis Valle Flori [sic]: Gravier, 1918

Telmatactis pseudoroseni: Carlgren, 1949

Telmatactis rufa: Corrêa, 1964

Telmatactis valle flori [sic]: Doumenc, 1973

Telmatactis cricoides: Cairns et al., 1986

Short description Pedal disc well-developed, $21-28 \mathrm{~mm}$ in diameter, pale-orange, translucent. Column cylindrical, 41-45 mm height and 38-40 $\mathrm{mm}$ diameter, divided into capitulum and scapus. Capitulum short, smooth, greyish; 
scapus robuts, wrinkled-texture, pale-orange. Oral disc slightly wider than column, $41-45 \mathrm{~mm}$ in diameter, smooth, whitish pale-brown, with dark-brown and reddish spots irregularly scattered; mouth dark-red. Tentacles hexamerously arranged in five cycles (about 96 in specimens examined), the inner cycles longer than outer ones, smooth, moderately short, cylindrical, with the tips widely swollen and blunt. Tentacle coloration variable, often whitish or pale-brown, with V or W shaped dark-brown or dark-red spots at its bases and with transversal white spots and reddish dots scattered along entire length. For further information on internal anatomy and cnidae see Belém \& Schlenz (1989), Cairns et al. (1986), and Wirtz $(1996,1997)$.

Habitat This species lives attached to hard substrate, under rocks of coral colonies, between 1.5-20.0 m.

Distribution Western Atlantic, from Bermuda to Brazil (Belém \& Schlenz 1989; Cairns et al. 1986; Varela 2001), and along the Caribbean Sea (González-Muñoz et al. 2012). Also has been reported in Eastern Atlantic, Mediterranean Sea, and Japan (Ocaña \& den Hartog 2002; Verrill 1868; Wirtz 1996, 1997). Agudo (1987) previously registered $T$. cricoides $(=T$. rufa $)$ in Venezuela (Table 1), inhabiting coral reefs.

\section{Telmatactis vernonia (Duchassaing \& Michelotti, 1864a) (Fig. 3j) Capnea Vernonia [sic] Duchassaing \& Michelotti, 1864a Phellia Vernonia [sic]: Verrill, 1869 Capnaea Vernonia [sic]: Duchassaing, 1870 Telmatactis vernonia: Cairns et al. 1986}

Short description Pedal disc well-developed, 4-10 mm in diameter, pale-orange, translucent. Column cylindrical, 5-11 mm height and 4-10 $\mathrm{mm}$ in diameter, divided into capitulum and scapus. Capitulum short, smooth, and greyish to pale-orange; scapus robuts, wrinkled-texture, pale-orange. Oral disc slightly wider than column, 5-12 $\mathrm{mm}$ in diameter, smooth, dark-brown, with white spots, and greenish and purple flashes; mouth brownish. Tentacles hexamerously arranged in five cycles (about 96 in specimens examined), the inner cycles longer than outer ones, smooth, short, cone-shape, tapering distally, pale-brown with purple flashes, and reddish transversal spots along its entire length. For further information on internal anatomy see Duchassaing \& Michelotti (1864a) and Cairns et al. (1986).

Habitat This species lives attached to hard substrate, under rocks or coral rubble, between 0.5-1.5 m.

Distribution Western Atlantic, reported in St. Thomas (Duchassaing \& Michelotti 1864a), Panamá
(Sebens \& DeRiemer 1977), and Bermuda (Cairns et al. 1986); this is the first record for Venezuela, found in Las Burbujas, Mochima, inhabiting under boulders in a rocky shore.

\author{
Order CERIANTHARIA Perrier, 1883 \\ Suborder PENICILARIA den Hartog, 1977 \\ Family ARACHNANTHIDAE McMurrich, 1910 \\ Isarachnanthus nocturnus (den Hartog, 1977) \\ (Fig. 3k) \\ Ceriantheopsis sp. Pax, 1924 \\ Arachnanthus nocturnus den Hartog, 1977 \\ Isarachnanthus nocturnus: Molodtsova, 2000
}

Short description Base rounded, bulb-shape, forming a physa. Column elongate, smooth, $15-30 \mathrm{~mm}$ in diameter, divided into capitulum and scapus. Capitulum white with bright-green flashes; scapus brown yellowish. Two type of tentacles: marginal and labial tentacles. Marginal tentacles long and slender (about 24 in number), with a coloration pattern of white and dark-brown transversal alternated rows along their entire length; labial tentacles short (about 44 in number), pale-brown. For further information on internal anatomy and cnidae see Molodtsova (2003), Stampar et al. (2012) and Stampar \& Morandini (2014).

Habitat This species inhabits shallow waters with the column completely burrowed in soft substrates such as sand or mud, and surrounded by a tube formed by ptychocists and secretions of mucous. It is commonly observed during night and sometimes during day light, between $10.0-27.0 \mathrm{~m}$.

Distribution Western Atlantic, from Bermuda to Brazil, along the Caribbean Sea (Cairns et al. 1986; den Hartog 1977; Molodtsova 2003; Stampar \& Morandini 2014; Stampar et al. 2012). Isarachnanthus nocturnus (= Arachnanthus nocturnus) has been previously recorded in Venezuela by Agudo (1987) (Table 1).

Order CORALLIMORPHARIA Carlgren, 1940 Family CORALLIMORPHIDAE Hertwig, 1882 Corynactis caribbeorum (den Hartog, 1980) (Fig. 3l)

Pseudocorynactis caribbeorum den Hartog, 1980

Pseudocorynactis sp.: Pires et al., 1992

Corynactis caribbeorum: Fautin, 2011

Short description Base flat and with irregular contour. Column short, stout, $20-25 \mathrm{~mm}$ in diameter 
and 28-32 $\mathrm{mm}$ in height, smooth, trump-shape when expanded and dome-shape when contracted. Base and column scarlet or bright-orange. Oral disc and mouth whitish and translucent. Tentacles long, about 120-160 in specimens examined, inner cycles longer than external ones, cone-shape but with capitated ends forming acrospheras. Tentacles whitish and translucent, acrospheras bright-orange. For further information on internal anatomy and cnidae see den Hartog (1980).

Habitat This species lives strongly attached to rocks or coral rubble, hidden below the rocks, between 15.0-25.0 m, but it has been reported down to $97 \mathrm{~m}$ depth (Agudo 1987).

Distribution Western Atlantic, along the Caribbean Sea, but it also has been reported in the Eastern Atlantic and Japan (den Hartog 1980; den Hartog et al. 1993; Fautin 2013; Ocaña \& den Hartog 2002; Wirtz 2001). Corynactis caribbeorum has previously been recorded in Venezuela (Agudo 1987; den Hartog 1980) (Table 1), inhabiting coral reefs and rocky shores.

Order ZOANTHARIA

Suborder BRACHYCNEMINA Haddon \& Shackleton, 1891

Family SPHENOPIDAE Hertwig, 1882
Palythoa caribaeorum Duchassaing \& Michelotti, 1860 (Fig. 4a)

Palythoa caribaeorum Duchassaing \& Michelotti, 1860

Palythoa caribea: Duchassaing \& Michelotti, 1866

Palythoa caraibeorum: Andres, 1883

Palythoa mammillosa: Verrill, 1901

Palythoa caribaea: Cairns et al., 1986

Short description Colonial polyps embedded in an extensive encrusting coenenchyme, thick and smooth, and with incrustations of sandy material. Colonies flat and variable in form. Polyps with short column (about 2-5 $\mathrm{mm}$ in height), pale-yellow or white. Tentacles in the margin, arranged in two cycles (about 15-24 each cycle in specimens examined), tapering distally, white-yellowish. Oral disc circular, concave; mouth slitlike. For further information on internal anatomy and cnidae see Sebens (1982), Varela et al. (2002), and Reimer et al. (2012).

Habitat This species lives attached to coral rocks, commonly in zones close to the reef's crest, often between $0.5-12.0 \mathrm{~m}$.

Distribution Widespread distribution throughout the Atlantic, from Bermuda to Brazil, along the entire Caribbean Sea and Gulf of Mexico, and along the west
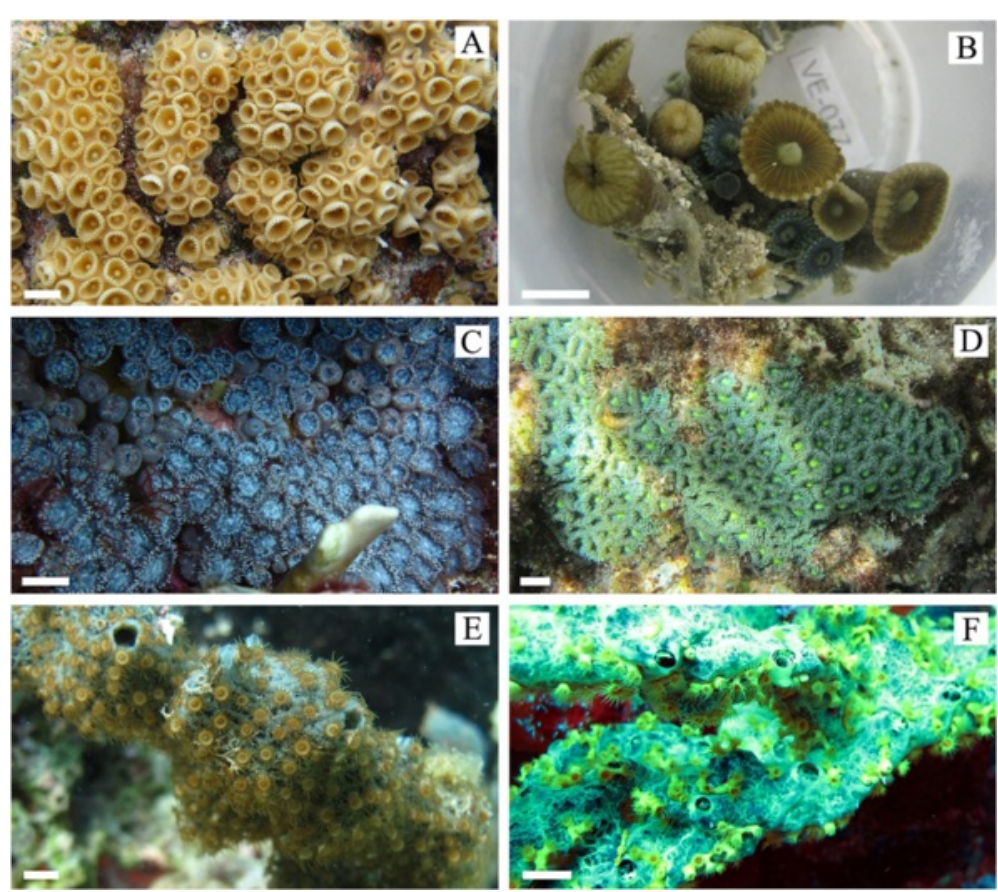

Fig. 4 a Palythoa caribaeorum, b Palythoa grandis, c Zoanthus cf. pulchellus, d Zoanthus sociatus, e Parazoanthus parasiticus, f Parazoanthus swiftii. Scale bar $=10 \mathrm{~mm}$ 
coast of Africa (Acosta et al. 2005; Alves-Santos et al. 2015; Fautin 2013; Reimer et al. 2010; Varela et al. 2002). This species has been previously registered in Venezuela (Agudo 1987; Bastidas \& Bone 1996) (Table 1), inhabiting coral reefs, seagrass meadows, mangroves, and rocky shores.

\section{Palythoa grandis (Verrill, 1900) \\ (Fig. 4b) \\ Protopalythoa grandis Verrill, 1900 \\ Palythoa grandis: Pax, 1910}

Short description Colonies of only few polyps that are joined by flat, stoloniferous or extensive encrusting coenenchyme; coenenchyme usually thinner than the free height of the polyps (Ryland \& Lancaster 2003). Column trumped-shape, smooth, but rough in appearance due to sandy incrustations, $15-35 \mathrm{~mm}$ in height and 10$15 \mathrm{~mm}$ in diameter, ochre-yellow or brown. Tentacles in the margin, arranged in two cycles (about 60 in specimens examined), tapering distally, brown. Oral disc broad, convex or umbrella-shape when completely expanded, sometimes with the borders recurved when contracted, 10-19 $\mathrm{mm}$ in diameter, dark-brown or olive-greenwith pale-green radial marks, and sometimes with a whitish or beige ring surrounding the slit-like mouth. For further information on internal anatomy see Verrill $(1900,1905)$ and Varela et al. (2002).

Habitat This species lives attached to rocks and coral rubble, often between $0.5-3.0 \mathrm{~m}$. Sometimes isolated polyps may occur (Verrill 1900). As other species closely related, this species has a tendency to form carpets, often intermingled with species of Zoanthus, which can grow between stolons and polyp clusters (Ryland \& Lancaster 2003) (Fig. 4b).

Distribution Western Atlantic, from Bermuda to Venezuela (Acosta et al. 2005; Verrill 1900). Agudo (1987) previously documented $P$. grandis in Venezuela (Table 1), inhabiting coral reefs and rocky shores.

\section{Family ZOANTHIDAE}

Zoanthus cf. pulchellus (Duchassaing \& Michelotti, 1864a)

(Fig. 4c)

Mamillifera pulchella Duchassaing \& Michelotti, 1864a

Zoanthus pulchellus: Duerden, 1898a

Short description Polyps embedded in a lamellar encrusting coenenchyme, forming colonies of several polyps. Column cylindrical, 5-25 $\mathrm{mm}$ in height and 5$10 \mathrm{~mm}$ in diameter, smooth and often without sandy incrustations, white to beige. Oral disc slightly wider than column, smooth, bluish with paler patterning; mouth slit-like, sometimes with dark triangular spots at each axial extremity. Tentacles in the margin, arranged in two cycles (about 60 in number), tapering distally, bluish or greyish. For further information on internal anatomy and cnidae see Duerden (1898a, 1902), Verrill (1900), Varela et al. (2002), and Reimer et al. (2012).

Remarks External anatomy of these specimens, including column shape and measurements, fits well with those described for Zoanthus pulchellus, except from coloration of the oral disc which is generally described as bright-green, pale-green, or yellow, with light radiating lines and sometimes with pink, brown, or yellow patterning (Duerden 1898a, 1902; Reimer et al. 2012; Verrill 1900).

Habitat This species lives attached to rocks or coral rubble, mostly in shallow waters, but not intertidal zones, between $0.5-1.0 \mathrm{~m}$.

Distribution Western Atlantic, from Jamaica to Brazil (Acosta et al. 2005; Alves-Santos et al. 2015; Fautin \& Daly 2009; Reimer et al. 2012; Varela et al. 2002). Agudo (1987) previously documented Z. pulchellus in Venezuela (Table 1), inhabiting coral reefs, seagrass meadows, mangroves, and rocky shores.

\section{Zoanthus sociatus (Ellis, 1768) \\ (Fig. 4d) \\ Actinia sociata Ellis, 1768 \\ Zoanthus sociata: Le Sueur, 1817 \\ Zoanthus sociatus: Ehrenberg, 1834 \\ Zoanthus nobilis: Duchassaing \& Michelotti, 1860 \\ Zoanthus proteus: Verrill, 1900}

Short description Polyps rising directly from a thin band-like stoloniferous coenenchyme, forming colonies of several polyps. Column club-shaped or cylindrical, 25-40 $\mathrm{mm}$ in height and $4-6 \mathrm{~mm}$ in diameter, smooth and often without sandy incrustations, white to beige. Oral disc slightly wider than distal column, smooth, olive-green, bluish or yellow; mouth slit-like, bright-green, sometimes surrounded by a dark-brown, yellow or greyish ring, or with dark triangular spots at each axial extremity. Tentacles in the margin, arranged in two cycles (about 48-60 in number), tapering distally, pale-green or greyish. For further information on internal anatomy and cnidae see Verrill (1900), Duerden (1902), Cairns et al. (1986), Varela et al. (2002), and Reimer et al. (2012). 
Habitat This species lives attached to rocks or coral rubble, mostly in shallow waters, but not on intertidal zones, between $1.0-5.0 \mathrm{~m}$.

Distribution Western Atlantic, from Bermuda to Brazil (Acosta et al. 2005; Alves-Santos et al. 2015; Cairns et al. 1986; Fautin \& Daly 2009; Reimer et al. 2012; Varela et al. 2002). Zoanthus sociatus has been previously registered in Venezuela (Agudo 1987) (Table 1), inhabiting coral reefs, seagrass meadows, mangroves, and rocky shores.

Suborder MACROCNEMINA Haddon \& Shackleton, 1891

Family PARAZOANTHIDAE Delage \& Hirouard, 1901

Parazoanthus parasiticus (Duchassaing \& Michelotti, 1860)

(Fig. 4e)

Zoanthus parasiticus Duchassaing \& Michelotti, 1860

Parazoanthus parasiticus: Verrill, 1900

Parazoanthus separatus: Duerden, 1900

Short description Polyps connected by a reticular coenenchyme, with the column embedded inside sponges. Oral disc and tentacles $4-10 \mathrm{~mm}$ in diameter in complete expansion. Oral disc 1-3 $\mathrm{mm}$ in diameter; oral disc and mouth yellow to yellow-brown; mouth slit-like. Tentacles in the margin, arranged in two cycles (about 24-28 in number), tapering distally, yellowish. For further information on internal anatomy see West (1979), Crocker \& Reiswig (1981), Cairns et al. (1986), and Varela et al. (2003).

Habitat This species lives attached to sponges of several species, including Cliona varians (Duchassaing \& Michelotti, 1864b), Cliona delitrix Pang, 1973, Callyspongia vaginalis (Lamarck, 1814), Niphates digitalis (Lamarck, 1814), Niphates erecta Duchassaing \& Michelotti, 1864b, and Spheciospongia sp. Marshall, 1892 (Varela et al. 2003), in the lagoon, fore-reef, and back-reef zones, between $1.0-35.0 \mathrm{~m}$.

Distribution Western Atlantic, from Bermuda to Venezuela, and along the Caribbean Sea (Acosta et al. 2005; Agudo 1987; Cairns et al. 1986; Fautin \& Daly 2009; Varela et al. 2003; West 1979). Parazoanthus parasiticus has previously been registered in Venezuela inhabiting coral reefs (Agudo 1987) (Table 1).

\section{Parazoanthus swiftii (Duchassaing \& Michelotti, 1860) (Fig. 4f) \\ Gemmaria Swiftii [sic] Duchassaing \& Michelotti, 1860 Gemmaria swiftii: Haddon \& Shackleton, 1891 \\ Parazoanthus swiftii: Duerden, 1898a}

Parazoanthus Swiftii [sic]: Duerden, 1898b

Palythoa Swiftii [sic]: Roule, 1900

Palythoa swiftii: Pax \& Müller, 1957

Short description Polyps connected by a reticular coenenchyme. Polyps situated above sponges, but not embedded. Oral disc and tentacles $12-15 \mathrm{~mm}$ in complete expansion. Oral disc and mouth are yellow or bright-orange; mouth slit-like. Tentacles in the margin, arranged in two cycles (about 24-28 in number), tapering distally, yellowish. For further information on internal anatomy see Duerden (1898a), West (1979), and Crocker \& Reiswig (1981).

Habitat This species lives attached to sponges of several species, including Clathria virgultosa (Lamarck, 1814), Iotrochota birotulata (Higgin, 1877), and Agelas conifera (Schmidt, 1870); inhabits the fore-reef, and back-reef zones, between $6.0-25.0 \mathrm{~m}$, but has been reported down to $50 \mathrm{~m}$ (Agudo 1987).

Distribution Western Atlantic, from Jamaica to Brazil (Acosta et al. 2005; Alves-Santos et al. 2015; Duerden 1898a; West 1979). Agudo (1987) previously documented P. swiftii in Venezuela (Table 1) inhabiting coral reefs.

\section{Sea anemone specimens of the collection of the MOHRB}

The collection of sea anemones of MOHBR is constituted by specimens collected over a relatively broad temporal range (1953-2012) by about a dozen different collectors (see Appendix 2). Most of the specimens include the basic information about them such as date of collection, locality, coordinates, and collector name. We included the available information of these specimens in Table 1, which shows the distribution of sea anemones documented along the coast of Venezuela, including previous and new data.

Of the 84 specimens examined from the MOHBR collection, 81 specimens were identified to species level and their current taxonomic status was confirmed or updated (see Table 1; Appendix 2). These specimens belong to 22 species: Actinostella flosculifera (11 specimens), Anemonia sargassensis (8 specimens), Bunodosoma cavernatum (1 specimen), Bunodosoma granuliferum (2 specimens), Condylactis gigantea (12 specimens), Bartholomea annulata (4 specimens), Exaiptasia pallida (6 specimens), Lebrunia coralligens (1 specimen), Lebrunia neglecta (5 specimens), Phymanthus crucifer (5 specimens), Stichodactyla helianthus (10 specimens), Bunodeopsis antilliensis (3 specimens), Calliactis tricolor (2 specimens), Homostichanthus duerdeni Carlgren, 1900 (1 specimen), Actinoporus elegans (1 specimen), Telmatactis cricoides (2 specimens), Palythoa caribaeorum (4 specimens), Zoanthus pulchellus (1 specimen), and Zoanthus sociatus (2 specimens), which were also documented during 
our surveys. The other three specimens could not be identified; however, they were originally labeled in the MOBHR collection as Haliplanella luciae (1 specimen) currently Diadumene lineata (Verrill, 1869) (Beneti et al. 2015; Fautin 2013), Palythoa variabilis (Duerden, 1898a), and Isaurus duchassaingi (Duchassaing \& Michelotti, 1860) (Table 1; Appendix 2).

\section{Discussion}

Comparison of previous records of sea anemone species in Venezuela and the findings of the present study

Fourty-nine shallow water species of sea anemones have been registered along coastal and coral reefs environments in Venezuela (Table 1) (Agudo 1987; Bastidas \& Bone 1996; Bitter-Soto 1999; Carrasquel 2012; den Hartog 1980; Knowlton \& Keller 1985; Liñero-Arana \& González 2008). In addition, Riemann-Zürneck (1986) documented the record of the actiniarian Monactis vestita (Gravier, 1918) in the Venezuela basin, between 4000-5000 m (see Table 1). Agudo (1987) recorded 27 species of the order Actiniaria, 4 of Ceriantharia, 3 of Corallimorpharia, and 13 of Zoanthidea along the central coast and islands in Venezuela (Table 1). In the present study, we found 24 of the 47 sea anemones species documented by Agudo (1987) while two actiniarian species, Anthopleura pallida and Telmatactis vernonia, are documented for the first time in Venezuela (see Table 1).

Among the 27 actiniarian species reported by Agudo (1987) that we did not find in our surveys, Actinia bermudensis (McMurrich, 1889a), Anthopleura krebsi (Duchassaing \& Michelotti, 1860), Isoaulactinia stelloides (McMurrich, 1889b) (= Bunodactis stelloides), and Homostichanthus duerdeni, are species that have been commonly reported in several localities along the Caribbean Sea or the Gulf of Mexico (González-Muñoz et al. 2012, 2013). Thus, it might be expected to find these species in Venezuela under a more extensive survey. On the other hand, the known distribution of other species documented by Agudo (1987), as Bunodosoma caissarum Corrêa in Belém, 1987 and Bunodosoma cangicum Belém \& Preslercravo, 1973 is restricted to South America, along the Brazilian coast (Fautin, 2013; Zamponi et al. 1998), and thus, the presence of these species in Venezuela is atypical or improbable. The species Bunodosoma kuekenthali Pax, 1910 (= B. kükenthali) has only been reported for Barbados (Lewis 1960; Pax 1910) but its taxonomic status remains unknown due to the lack of recent studies about the species. The species Anthopleura cascaia Corrêa, 1964 is considered as nomen nudum according with the International Code of Zoological Nomenclature (ICZN 1999), due that it was originally described in a thesis study (Corrêa 1964), and no other description has been published to date for the species (Fautin, 2013). Bartholomea werneri
Watzl, 1922 was recently synonymized with $B$. annulata by Grajales \& Rodríguez (2014). Agudo (1987) also documented Scolanthus curacaoensis (Pax, 1924) (= Edwadsia horstii), which has a restricted distribution in the Laguna de Chacopata, (Liñero-Arana \& González 2008), and in Curaçao (Pax 1924), and one unidentified species of genus Phymactis Milne-Edwards, 1857 (reported as Phymactis sp). Except for $H$. duerdeni (one specimen available previously deposited at MOHBR, see Appendix 2), it is difficult to assess or confirm the certainty of the other 10 actiniarian records because voucher specimens were not available.

From the three species of corallimorpharians reported by Agudo (1987), we only documented Corynactis caribbeorum (= Pseudocorynactis caribbeorum). This species was only found in Chichiriviche de la Costa, and has been previously reported for Venezuela by den Hartog (1980), outside the Isla Tortuga and in front to Camuri Chico coast. Discosoma carlgreni (Watzl, 1922) and Rhodactis osculifera (Le Sueur, 1817) (= Discosoma sanctithomae) are the other two species of corallimorpharians reported by Agudo (1987) in Venezuela (Table 1). These two corallimorpharian species, as well as Ricordea florida Duchassaing \& Michelotti, 1860, are among the most commonly known species of corallimorpharians found in coral reefs along the Caribbean Sea and Gulf of Mexico (den Hartog 1980; Fautin \& Daly 2009). Thus, despite we could not find these corallimorpharians at any of our surveys, it is possible that these species are actually present in Venezuela as they have a wide range of distribution in the Caribbean.

For the cerianthid species, Agudo (1987) documented Ceriantheopsis americanus (Agassiz in Verrill, 1864), Ceriantheomorphe brasiliensis Carlgren, 1931, Pachycerianthus curacaoensis den Hartog, 1977, and Isarachnanthus nocturnus (= Arachnanthus nocturnus) in Venezuela (Table 1). Ceriantheopsis americanus has been reported in the Northwest Atlantic, Caribbean Sea, Uruguay, and China (Fautin 2013; Molodtsova 2009). Ceriantheomorphe brasiliensis has been reported in the United States-Texas and Brazil (Carlgren 1931; Carlgren \& Hedgpeth 1952; Molodtsova 2009), and P. curacaoensis in Curaçao (den Hartog 1977). In our surveys we only documented I. nocturnus in Chichiriviche de la Costa, but we have also observed another two species of tube anemones near to Isla de Cubagua that were not collected, and thus remain unidentified. More detailed taxonomic studies about cerianthid species in Venezuela are needed, in order to confirm the number of species for the region.

Out of the 13 zoanthid species previously reported in Venezuela (Agudo 1987; Bastidas \& Bone 1996), we only found six (Table 1), one of them reported here as Zoanthus cf. pulchellus. Agudo (1987) also documented Zoanthus proteus Verrill, 1900 which is currently considered as synonym of $Z$. sociatus according to Reimer 
et al. (2012), and Palythoa mammillosa (Ellis \& Solander, 1786), which has been suggested as synonym of $P$. caribaeorum (Sebens 1982). Agudo (1987) reported Palythoa variabilis (Duerden, 1898a) which is distributed throughout the Caribbean and the Atlantic coast of South America (Alves-Santos et al. 2015; Reimer et al. 2012), but also has been documented as amphi-atlantic (Reimer et al. 2010). Zoanthus solanderi Le Sueur, 1817, Parazoanthus puertoricense West, 1979, P. catenularis (Duchassaing \& Michelotti, 1860), and Epizoanthus cutressi West, 1979, are also commonly included in some inventories of sea anemones of the Caribbean Sea (e.g. Ocaña et al. 2007; Reimer et al. 2012; West 1979), and thus, they are also expected to occur in Venezuela as reported by Agudo (1987). The taxonomic status of zoanthid species, mainly those of the genera Palythoa and Zoanthus, is currently considered as chaotic due to the great intraspecific variability present in several species, and thus the true number of valid species of these genera for the Caribbean is unknown (Reimer et al. 2010, 2012). However, recent studies have suggested the utility of molecular markers to distinguish among species (Alves-Santos et al. 2015; Reimer et al. 2012). Further detailed taxonomic studies of shallow water zoanthids in Venezuela are needed in order to facilitate identification to the species level.

\section{Sea anemone specimens of the collection MOHBR}

Among the 84 specimens of the collection of the MOHRB, the identification of the specimens labelled as Palythoa variabilis, Isaurus duchassaingi, and Diadumene lineata (= Haliplanella luciae), could not be corroborated due to the poor condition of the preserved specimens. However, these zoanthid species are commonly reported in Caribbean inventories of sea anemones (Acosta et al. 2005; Cairns et al. 1986; Reimer et al. 2012), and D. lineata is known as a cosmopolitan species (Fautin 2013). Thus, we might expect the presence of these two species in Venezuela, but their occurrence needs to be corroborated. The external anatomy of the specimens labelled as Zoanthus pulchellus fits well with those previously described for this species: polyps embedded in a thin lamellar coenenchyma rather than stoloniferous, with the column approximately $4-6 \mathrm{~mm}$ in diameter and 4 to over $30 \mathrm{~mm}$ in height, and 50-60 short tentacles (Reimer et al. 2012). Thus, although there is no information about the coloration pattern of these preserved polyps, we agree with the previous identification that this specimen belongs to $Z$. pulchellus.

\section{Conclusions}

Based on the current taxonomic status and the general distribution patterns of the 47 species documented by
Agudo (1987), we suggest that at least eight of his records are currently invalid or erroneous, and only 39 sea anemone species documented by him could be found in Venezuela, of which 24 species are documented in the present study. Taking into account the previous records of D. lineata, and I. duchassaingi in the collection of the MOHBR, and that of Monactis vestita reported by Riemann (1986), plus the two new records of sea anemones documented in our surveys, this study increases to 44 the number of records of sea anemones that might be found in Venezuela.

\section{Methods}

The Caribbean coastline of Venezuela extends approximately 2,695 km, plus an important insular region constituted by 14 archipelagos composed of 300 island and keys (Conde \& Carmona-Suárez 2003; Miloslavich et al. 2005). Sampling was conducted in November 2012 in four marine reserves along the Venezuelan coast: Morrocoy National Park $\left(10^{\circ} 53^{\prime} 2.51^{\prime \prime} \mathrm{N}, 68^{\circ} 12^{\prime} 43.66^{\prime \prime} \mathrm{W}\right)$,

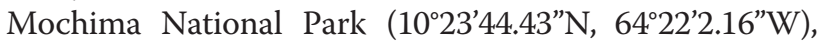
Archipiélago de Los Roques National Park (1146’21.67”N, $\left.66^{\circ} 42^{\prime} 8.67^{\prime \prime} \mathrm{W}\right)$, and Laguna de La Restinga National Park $\left(10^{\circ} 58^{\prime} 36.75^{\prime \prime} \mathrm{N}, 64^{\circ} 9^{\prime} 4.40^{\prime \prime} \mathrm{W}\right)$ (Fig. 1). Additionally, we include observations and collections made in Isla de Cubagua $\left(10^{\circ} 50^{\prime} 8.40^{\prime \prime} \mathrm{N}, 64^{\circ} 8^{\prime} 51.74^{\prime \prime} \mathrm{W}\right)$ and Chichiriviche de la Costa $\left(10^{\circ} 33^{\prime} 12.18^{\prime \prime} \mathrm{N}, 67^{\circ} 14^{\prime} 24.43^{\prime \prime} \mathrm{W}\right)$ in the central coast of Venezuela (Fig. 1). Sampled habitats included sandy bottoms, rocky shore, seagrass meadows, coral rubble, coral reefs and mangrove roots. Representative specimens of each species were collected by hand, either by snorkeling or scuba diving, and using a hammer and a chisel. Specimens were photographed in situ and habitat characteristics were recorded. Collected samples were transferred to the laboratory and maintained in an aquarium to photograph their color while alive. Specimens were relaxed using menthol crystals in seawater, subsequently fixed in $10 \%$ formalin seawater, and their diagnostic characters were examined for identification. Voucher specimens of each identified species were deposited in the collection of the MOHBR (see Appendix 1). In addition, eighty-four specimens of sea anemones previously deposited by other authors in the collection at MOHBR were examined.

We followed the taxonomic classification implemented in Fautin (2013) with modifications from Rodríguez et al. (2014). Taxa were organized in suborder and family, and listed in alphabetical order. External appearance and measurements described for each species were based in living specimens collected in Venezuela. The synonym list for each species only contains reference to the first citation of the species by a particular name. 


\section{Appendix 1}

Table 2 Specimens collected during the present study

\begin{tabular}{|c|c|c|c|c|c|c|c|c|}
\hline No. & Code & MOHBR & Species & National Park & Locality & State & Latitude N & Longitude W \\
\hline 1 & RG-001 & I-1576 & Lebrunia neglecta & Morrocoy & Cayo sombrero & Falcon & $10^{\circ} 53^{\prime} 2.51^{\prime \prime}$ & $68^{\circ} 12^{\prime} 43.66^{\prime \prime}$ \\
\hline 2 & RG-002 & |-1577 & Lebrunia coralligens & Morrocoy & Cayo sombrero & Falcon & $10^{\circ} 53^{\prime} 2.51^{\prime \prime}$ & $68^{\circ} 12^{\prime} 43.66^{\prime \prime}$ \\
\hline 3 & RG-003 & $\mid-1578$ & Lebrunia coralligens & Morrocoy & Cayo sombrero & Falcon & $10^{\circ} 53^{\prime} 2.51^{\prime \prime}$ & $68^{\circ} 12^{\prime} 43.66^{\prime \prime}$ \\
\hline 4 & RG-004 & |-1579 & Palythoa caribaeorum & Morrocoy & Cayo sombrero & Falcon & $10^{\circ} 53^{\prime} 2.51^{\prime \prime}$ & $68^{\circ} 12^{\prime} 43.66^{\prime \prime}$ \\
\hline 5 & RG-005 & $\mid-1580$ & Bartholomea annulata & Morrocoy & Tumba 4 & Falcon & $10^{\circ} 50^{\prime} 13.86^{\prime \prime}$ & $68^{\circ} 14^{\prime} 14.08^{\prime \prime}$ \\
\hline 6 & RG-006 & $\mid-1581$ & Exaiptasia pallida & Morrocoy & Muelle & Falcon & $10^{\circ} 51^{\prime} 27.03^{\prime \prime}$ & $68^{\circ} 16^{\prime} 48.12^{\prime \prime}$ \\
\hline 7 & RG-007 & |-1582 & Parazoanthus parasiticus & Morrocoy & Cayo sombrero & Falcon & $10^{\circ} 53^{\prime} 2.51^{\prime \prime}$ & $68^{\circ} 12^{\prime} 43.66^{\prime \prime}$ \\
\hline 8 & RG-008 & $\mid-1583$ & Actinostella flosculifera & Morrocoy & Boca Seca & Falcon & $10^{\circ} 49^{\prime} 58.73^{\prime \prime}$ & $68^{\circ} 14^{\prime} 10.60^{\prime \prime}$ \\
\hline 9 & RG-009 & |-1584 & Anthopleura pallida & Morrocoy & Boca Seca & Falcon & $10^{\circ} 49^{\prime} 58.73^{\prime \prime}$ & $68^{\circ} 14^{\prime} 10.60^{\prime \prime}$ \\
\hline 10 & RG-010 & $\mid-1585$ & Bunodosoma granuliferum & Morrocoy & Boca Seca & Falcon & $10^{\circ} 49^{\prime} 58.73^{\prime \prime}$ & $68^{\circ} 14^{\prime} 10.60^{\prime \prime}$ \\
\hline 11 & RG-011 & ।-1586 & Lebrunia coralligens & Morrocoy & Boca Seca & Falcon & $10^{\circ} 49^{\prime} 58.73^{\prime \prime}$ & $68^{\circ} 14^{\prime} 10.60^{\prime \prime}$ \\
\hline 12 & RG-012 & |-1587 & Actinoporus elegans & Morrocoy & Boca Seca & Falcon & $10^{\circ} 49^{\prime} 58.73^{\prime \prime}$ & $68^{\circ} 14^{\prime} 10.60^{\prime \prime}$ \\
\hline 13 & RG-013 & $\mid-1588$ & Actiniidae sp. & Morrocoy & Boca Seca & Falcon & $10^{\circ} 49^{\prime} 58.73^{\prime \prime}$ & $68^{\circ} 14^{\prime} 10.60^{\prime \prime}$ \\
\hline 14 & RG-014 & $\mid-1589$ & Exaiptasia pallida & Morrocoy & Boca Seca & Falcon & $10^{\circ} 49^{\prime} 58.73^{\prime \prime}$ & $68^{\circ} 14^{\prime} 10.60^{\prime \prime}$ \\
\hline 15 & RG-015 & $\mid-1590$ & Exaiptasia pallida & Morrocoy & Boca Seca & Falcon & $10^{\circ} 49^{\prime} 58.73^{\prime \prime}$ & $68^{\circ} 14^{\prime} 10.60^{\prime \prime}$ \\
\hline 16 & RG-016 & |-1591 & Bartholomea annulata & Morrocoy & Boca Seca & Falcon & $10^{\circ} 49^{\prime} 58.73^{\prime \prime}$ & $68^{\circ} 14^{\prime} 10.60^{\prime \prime}$ \\
\hline 17 & RG-017 & |-1592 & Palythoa caribaeorum & Morrocoy & Boca Seca & Falcon & $10^{\circ} 49^{\prime} 58.73^{\prime \prime}$ & $68^{\circ} 14^{\prime} 10.60^{\prime \prime}$ \\
\hline 18 & RG-018 & |-1593 & Zoanthus sociatus & Morrocoy & Boca Seca & Falcon & $10^{\circ} 49^{\prime} 58.73^{\prime \prime}$ & $68^{\circ} 14^{\prime} 10.60^{\prime \prime}$ \\
\hline 19 & RG-019 & |-1594 & Zoanthus sociatus & Morrocoy & Boca Seca & Falcon & $10^{\circ} 49^{\prime} 58.73^{\prime \prime}$ & $68^{\circ} 14^{\prime} 10.60^{\prime \prime}$ \\
\hline 20 & RG-020 & |-1595 & Zoanthus sociatus & Morrocoy & Boca Seca & Falcon & $10^{\circ} 49^{\prime} 58.73^{\prime \prime}$ & $68^{\circ} 14^{\prime} 10.60^{\prime \prime}$ \\
\hline 21 & RG-021 & |-1596 & Exaiptasia pallida & Morrocoy & Las Luisas & Falcon & $10^{\circ} 51^{\prime} 30.34^{\prime \prime}$ & $68^{\circ} 18^{\prime} 35.22^{\prime \prime}$ \\
\hline 22 & RG-022 & |-1597 & Bunodeopsis antilliensis & Morrocoy & Las Luisas & Falcon & $10^{\circ} 51^{\prime} 30.34^{\prime \prime}$ & $68^{\circ} 18^{\prime} 35.22^{\prime \prime}$ \\
\hline 23 & RG-023 & $\mid-1598$ & Lebrunia coralligens & Morrocoy & Cayo sombrero & Falcon & $10^{\circ} 53^{\prime} 2.51^{\prime \prime}$ & $68^{\circ} 12^{\prime} 43.66^{\prime \prime}$ \\
\hline 24 & RG-024 & |-1599 & Actiniidae sp. & Morrocoy & Cayo sombrero & Falcon & $10^{\circ} 53^{\prime} 2.51^{\prime \prime}$ & $68^{\circ} 12^{\prime} 43.66^{\prime \prime}$ \\
\hline 25 & RG-025 & $\mid-1600$ & Phymantus crucifer & Mochima & Punta la Cruz & Sucre & $10^{\circ} 23^{\prime} 44.43^{\prime \prime}$ & $64^{\circ} 22^{\prime} 2.16^{\prime \prime}$ \\
\hline 26 & RG-026 & |-1601 & Lebrunia coralligens & Mochima & Punta la Cruz & Sucre & $10^{\circ} 23^{\prime} 44.43^{\prime \prime}$ & $64^{\circ} 22^{\prime} 2.16^{\prime \prime}$ \\
\hline 27 & RG-027 & $\mid-1602$ & Parazoanthus parasiticus & Mochima & Punta la Cruz & Sucre & $10^{\circ} 23^{\prime} 44.43^{\prime \prime}$ & $64^{\circ} 22^{\prime} 2.16^{\prime \prime}$ \\
\hline 28 & RG-030 & $\mid-1603$ & Condylactis gigantea & Mochima & Punta la Cruz & Sucre & $10^{\circ} 23^{\prime} 44.43^{\prime \prime}$ & $64^{\circ} 22^{\prime} 2.16^{\prime \prime}$ \\
\hline 29 & RG-031 & |-1604 & Condylactis gigantea & Mochima & Punta la Cruz & Sucre & $10^{\circ} 23^{\prime} 44.43^{\prime \prime}$ & $64^{\circ} 22^{\prime} 2.16^{\prime \prime}$ \\
\hline 30 & RG-032 & $\mid-1605$ & Lebrunia neglecta & Mochima & Punta la Cruz & Sucre & $10^{\circ} 23^{\prime} 44.43^{\prime \prime}$ & $64^{\circ} 22^{\prime} 2.16^{\prime \prime}$ \\
\hline 31 & RG-033 & $\mid-1606$ & Exaiptasia pallida & Mochima & Punta la Cruz & Sucre & $10^{\circ} 23^{\prime} 44.43^{\prime \prime}$ & $64^{\circ} 22^{\prime} 2.16^{\prime \prime}$ \\
\hline 32 & RG-034 & |-1607 & Bartholomea annulata & Mochima & Punta la Cruz & Sucre & $10^{\circ} 23^{\prime} 44.43^{\prime \prime}$ & $64^{\circ} 22^{\prime} 2.16^{\prime \prime}$ \\
\hline 33 & RG-035 & $\mid-1608$ & Phymanthus crucifer & Mochima & Punta la Cruz & Sucre & $10^{\circ} 23^{\prime} 44.43^{\prime \prime}$ & $64^{\circ} 22^{\prime} 2.16^{\prime \prime}$ \\
\hline 34 & RG-036 & $\mid-1609$ & Phymanthus crucifer & Mochima & Punta la Cruz & Sucre & $10^{\circ} 23^{\prime} 44.43^{\prime \prime}$ & $64^{\circ} 22^{\prime} 2.16^{\prime \prime}$ \\
\hline 35 & RG-037 & $\mid-1610$ & Phymanthus crucifer & Mochima & Punta la Cruz & Sucre & $10^{\circ} 23^{\prime} 44.43^{\prime \prime}$ & $64^{\circ} 22^{\prime} 2.16^{\prime \prime}$ \\
\hline 36 & RG-038 & $\mid-1611$ & Phymanthus crucifer & Mochima & Punta la Cruz & Sucre & $10^{\circ} 23^{\prime} 44.43^{\prime \prime}$ & $64^{\circ} 22^{\prime} 2.16^{\prime \prime}$ \\
\hline 37 & RG-039 & $\mid-1612$ & Exaiptasia pallida & Mochima & Punta la Cruz & Sucre & $10^{\circ} 23^{\prime} 44.43^{\prime \prime}$ & $64^{\circ} 22^{\prime} 2.16^{\prime \prime}$ \\
\hline 38 & RG-040 & |-1613 & Exaiptasia pallida & Mochima & Manglar & Sucre & $10^{\circ} 22^{\prime} 18.17^{\prime \prime}$ & $64^{\circ} 20^{\prime} 12.33^{\prime \prime}$ \\
\hline 39 & RG-041 & In progress & Telmatactis cricoides & Mochima & Punta la Cruz & Sucre & $10^{\circ} 23^{\prime} 44.43^{\prime \prime}$ & $64^{\circ} 22^{\prime} 2.16^{\prime \prime}$ \\
\hline 40 & RG-042 & $\mid-1614$ & Lebrunia coralligens & Mochima & Las burbujas & Sucre & $10^{\circ} 21^{\prime} 6.03^{\prime \prime}$ & $64^{\circ} 24^{\prime} 45.86^{\prime \prime}$ \\
\hline 41 & RG-043 & |-1615 & Telmatactis vernonia & Mochima & Las burbujas & Sucre & $10^{\circ} 21^{\prime} 6.03^{\prime \prime}$ & $64^{\circ} 24^{\prime} 45.86^{\prime \prime}$ \\
\hline 42 & VE-003 & |-1616 & Actinostella flosculifera & Isla Cubagua & Las Cabeceras & Nueva Esparta & $10^{\circ} 50^{\prime} 8.40^{\prime \prime}$ & $64^{\circ} 8^{\prime} 51.74^{\prime \prime}$ \\
\hline
\end{tabular}


Table 2 Specimens collected during the present study (Continued)

\begin{tabular}{|c|c|c|c|c|c|c|c|c|}
\hline 43 & VE-004 & $\mid-1617$ & Exaiptasia pallida & Isla Cubagua & Las Cabeceras & Nueva Esparta & $10^{\circ} 50^{\prime} 8.40^{\prime \prime}$ & $64^{\circ} 8^{\prime} 51.74^{\prime \prime}$ \\
\hline 44 & VE-005 & $\mid-1618$ & Zoanthus sociatus & Isla Cubagua & Las Cabeceras & Nueva Esparta & $10^{\circ} 50^{\prime} 8.40^{\prime \prime}$ & $64^{\circ} 8^{\prime} 51.74^{\prime \prime}$ \\
\hline 45 & VE-007 & $\mid-1619$ & Actinostella flosculifera & Isla Cubagua & Las Cabeceras & Nueva Esparta & $10^{\circ} 50^{\prime} 8.40^{\prime \prime}$ & $64^{\circ} 8^{\prime} 51.74^{\prime \prime}$ \\
\hline 46 & VE-008 & $\mid-1620$ & Exaiptasia pallida & Isla Cubagua & Las Cabeceras & Nueva Esparta & $10^{\circ} 50^{\prime} 8.40^{\prime \prime}$ & $64^{\circ} 8^{\prime} 51.74^{\prime \prime}$ \\
\hline 47 & VE-010 & $\mid-1621$ & Stichodactyla helianthus & Isla Cubagua & Las Cabeceras & Nueva Esparta & $10^{\circ} 50^{\prime} 8.40^{\prime \prime}$ & $64^{\circ} 8^{\prime} 51.74^{\prime \prime}$ \\
\hline 48 & VE-012 & |-1622 & Stichodactyla helianthus & Isla Cubagua & Las Cabeceras & Nueva Esparta & $10^{\circ} 50^{\prime} 8.40^{\prime \prime}$ & $64^{\circ} 8^{\prime} 51.74^{\prime \prime}$ \\
\hline 49 & VE-013 & $\mid-1623$ & Phymanthus crucifer & Isla Cubagua & Las Cabeceras & Nueva Esparta & $10^{\circ} 50^{\prime} 8.40^{\prime \prime}$ & $64^{\circ} 8^{\prime} 51.74^{\prime \prime}$ \\
\hline 50 & VE-015 & $\mid-1624$ & Stichodactyla helianthus & Isla Cubagua & Las Cabeceras & Nueva Esparta & $10^{\circ} 50^{\prime} 8.40^{\prime \prime}$ & $64^{\circ} 8^{\prime} 51.74^{\prime \prime}$ \\
\hline 51 & VE-016 & $\mid-1625$ & Calliactis tricolor & Isla Cubagua & Las Cabeceras & Nueva Esparta & $10^{\circ} 50^{\prime} 8.40^{\prime \prime}$ & $64^{\circ} 8^{\prime} 51.74^{\prime \prime}$ \\
\hline 52 & VE-017 & $\mid-1626$ & Bartholomea annulata & Isla Cubagua & Las Cabeceras & Nueva Esparta & $10^{\circ} 50^{\prime} 8.40^{\prime \prime}$ & $64^{\circ} 8^{\prime} 51.74^{\prime \prime}$ \\
\hline 53 & VE-018 & |-1627 & Phymanthus crucifer & Isla Cubagua & Las Cabeceras & Nueva Esparta & $10^{\circ} 50^{\prime} 8.40^{\prime \prime}$ & $64^{\circ} 8^{\prime} 51.74^{\prime \prime}$ \\
\hline 54 & VE-019 & $\mid-1628$ & Bunodosoma cavernatum & Isla Cubagua & Las Cabeceras & Nueva Esparta & $10^{\circ} 50^{\prime} 8.40^{\prime \prime}$ & $64^{\circ} 8^{\prime} 51.74^{\prime \prime}$ \\
\hline 55 & VE-045 & $\mid-1629$ & Zoanthus cf. pulchellus & Los Roques & Boca de Cote & Dependencias Federales & $11^{\circ} 46^{\prime} 21.67^{\prime \prime}$ & $66^{\circ} 42^{\prime} 8.67^{\prime \prime}$ \\
\hline 56 & VE-046 & I-1630 & Parazoanthus swiftii & Los Roques & Boca de Cote & Dependencias Federales & $11^{\circ} 46^{\prime} 21.67^{\prime \prime}$ & $66^{\circ} 42^{\prime} 8.67^{\prime \prime}$ \\
\hline 57 & VE-047 & |-1631 & Condylactis gigantea & Los Roques & Boca de Cote & Dependencias Federales & $11^{\circ} 46^{\prime} 21.67^{\prime \prime}$ & $66^{\circ} 42^{\prime} 8.67^{\prime \prime}$ \\
\hline 58 & VE-049 & $\mid-1632$ & Exaiptasia pallida & Los Roques & Isla Larga & Dependencias Federales & $11^{\circ} 55^{\prime} 40.66^{\prime \prime}$ & $66^{\circ} 45^{\prime} 3.05^{\prime \prime}$ \\
\hline 59 & VE-050 & |-1633 & Actinostella flosculifera & Los Roques & Arena y Manglar & Dependencias Federales & $11^{\circ} 53^{\prime} 9.81^{\prime \prime}$ & $66^{\circ} 50^{\prime} 49.98^{\prime \prime}$ \\
\hline 60 & VE-052 & |-1634 & Actiniidae sp. & Los Roques & Arena y Manglar & Dependencias Federales & $11^{\circ} 53^{\prime} 9.81^{\prime \prime}$ & $66^{\circ} 50^{\prime} 49.98^{\prime \prime}$ \\
\hline 61 & VE-053 & |-1635 & Laviactis lucida & Los Roques & La Herradura & Dependencias Federales & $11^{\circ} 48^{\prime} 0.97^{\prime \prime}$ & $66^{\circ} 53^{\prime} 5.61^{\prime \prime}$ \\
\hline 62 & VE-054 & |-1636 & Lebrunia coralligens & Los Roques & Dos Mosquises & Dependencias Federales & $11^{\circ} 47^{\prime} 32.72^{\prime \prime}$ & $66^{\circ} 53^{\prime} 37.69^{\prime \prime}$ \\
\hline 63 & VE-055 & |-1637 & Lebrunia coralligens & Los Roques & Dos Mosquises & Dependencias Federales & $11^{\circ} 47^{\prime} 32.72^{\prime \prime}$ & $66^{\circ} 53^{\prime} 37.69^{\prime \prime}$ \\
\hline 64 & VE-056 & $\mid-1638$ & Lebrunia coralligens & Los Roques & Dos Mosquises & Dependencias Federales & $11^{\circ} 47^{\prime} 32.72^{\prime \prime}$ & $66^{\circ} 53^{\prime} 37.69^{\prime \prime}$ \\
\hline 65 & VE-057 & |-1639 & Stichodactyla helianthus & Los Roques & Dos Mosquises & Dependencias Federales & $11^{\circ} 47^{\prime} 36.57^{\prime \prime}$ & $66^{\circ} 53^{\prime} 17.43^{\prime \prime}$ \\
\hline 66 & VE-064 & $\mid-1640$ & Anemonia sargassensis & Isla Cubagua & Las Cabeceras & Nueva Esparta & $10^{\circ} 50^{\prime} 8.40^{\prime \prime}$ & $64^{\circ} 8^{\prime} 51.74^{\prime \prime}$ \\
\hline 67 & VE-065 & |-1641 & Stichodactyla helianthus & Isla Cubagua & Las Cabeceras & Nueva Esparta & $10^{\circ} 50^{\prime} 8.40^{\prime \prime}$ & $64^{\circ} 8^{\prime} 51.74^{\prime \prime}$ \\
\hline 68 & VE-066 & |-1642 & Stichodactyla helianthus & Isla Cubagua & Las Cabeceras & Nueva Esparta & $10^{\circ} 50^{\prime} 8.40^{\prime \prime}$ & $64^{\circ} 8^{\prime} 51.74^{\prime \prime}$ \\
\hline 69 & VE-067 & |-1643 & Anemonia sargassensis & Isla Cubagua & Las Cabeceras & Nueva Esparta & $10^{\circ} 50^{\prime} 8.40^{\prime \prime}$ & $64^{\circ} 8^{\prime} 51.74^{\prime \prime}$ \\
\hline 70 & VE-069 & $\mid-1644$ & Actinostella flosculifera & Isla Cubagua & Las Cabeceras & Nueva Esparta & $10^{\circ} 50^{\prime} 8.40^{\prime \prime}$ & $64^{\circ} 8^{\prime} 51.74^{\prime \prime}$ \\
\hline 71 & VE-072 & $\mid-1645$ & Condylactis gigantea & Isla Cubagua & Las Cabeceras & Nueva Esparta & $10^{\circ} 50^{\prime} 8.40^{\prime \prime}$ & $64^{\circ} 8^{\prime} 51.74^{\prime \prime}$ \\
\hline 72 & VE-073 & |-1646 & Phymanthus crucifer & Isla Cubagua & Las Cabeceras & Esparta & $10^{\circ} 50^{\prime} 8.40^{\prime \prime}$ & $64^{\circ} 8^{\prime} 51.74^{\prime \prime}$ \\
\hline 73 & VE-074 & |-1647 & Phymanthus crucifer & Isla Cubagua & Las Cabeceras & Nueva Esparta & $10^{\circ} 50^{\prime} 8.40^{\prime \prime}$ & $64^{\circ} 8^{\prime} 51.74^{\prime \prime}$ \\
\hline 74 & VE-075 & $\mid-1648$ & Phymanthus crucifer & Isla Cubagua & Las Cabeceras & Nueva Esparta & $10^{\circ} 50^{\prime} 8.40^{\prime \prime}$ & $64^{\circ} 8^{\prime} 51.74^{\prime \prime}$ \\
\hline 75 & VE-076 & |-1649 & Phymanthus crucifer & Isla Cubagua & Las Cabeceras & Nueva Esparta & $10^{\circ} 50^{\prime} 8.40^{\prime \prime}$ & $64^{\circ} 8^{\prime} 51.74^{\prime \prime}$ \\
\hline 76 & VE-077 & $\mid-1650$ & Palythoa grandis & Isla Cubagua & Las Cabeceras & Nueva Esparta & $10^{\circ} 50^{\prime} 8.40^{\prime \prime}$ & $64^{\circ} 8^{\prime} 51.74^{\prime \prime}$ \\
\hline 77 & VE-078 & $\mid-1651$ & Palythoa grandis & Isla Cubagua & Las Cabeceras & Nueva Esparta & $10^{\circ} 50^{\prime} 8.40^{\prime \prime}$ & $64^{\circ} 8^{\prime} 51.74^{\prime \prime}$ \\
\hline 78 & VE-079 & |-1652 & Parazoanthus parasiticus & Isla Cubagua & Las Cabeceras & Nueva Esparta & $10^{\circ} 50^{\prime} 8.40^{\prime \prime}$ & $64^{\circ} 8^{\prime} 51.74^{\prime \prime}$ \\
\hline 79 & VE-080 & $\mid-1653$ & Phymanthus crucifer & Isla Cubagua & Las Cabeceras & Nueva Esparta & $10^{\circ} 50^{\prime} 8.40^{\prime \prime}$ & $64^{\circ} 8^{\prime} 51.74^{\prime \prime}$ \\
\hline 80 & VE-081 & |-1654 & Stichodactyla helianthus & Isla Cubagua & Las Cabeceras & Nueva Esparta & $10^{\circ} 50^{\prime} 8.40^{\prime \prime}$ & $64^{\circ} 8^{\prime} 51.74^{\prime \prime}$ \\
\hline 81 & VE-082 & |-1655 & Actiniidae sp. & Isla Cubagua & Las Cabeceras & Nueva Esparta & $10^{\circ} 50^{\prime} 8.40^{\prime \prime}$ & $64^{\circ} 8^{\prime} 51.74^{\prime \prime}$ \\
\hline 82 & VE-085 & |-1656 & Bartholomea annulata & Isla Cubagua & Las Cabeceras & Nueva Esparta & $10^{\circ} 50^{\prime} 8.40^{\prime \prime}$ & $64^{\circ} 8^{\prime} 51.74^{\prime \prime}$ \\
\hline 83 & VE-086 & |-1657 & Phymanthus crucifer & Isla Cubagua & Las Cabeceras & Nueva Esparta & $10^{\circ} 50^{\prime} 8.40^{\prime \prime}$ & $64^{\circ} 8^{\prime} 51.74^{\prime \prime}$ \\
\hline 84 & VE-089 & $\mid-1658$ & Palythoa caribaeorum & Isla Cubagua & Las Cabeceras & Nueva Esparta & $10^{\circ} 50^{\prime} 8.40^{\prime \prime}$ & $64^{\circ} 8^{\prime} 51.74^{\prime \prime}$ \\
\hline 85 & VE-090 & I-1659 & Exaiptasia pallida & Isla Cubagua & Las Cabeceras & Nueva Esparta & $10^{\circ} 50^{\prime} 8.40^{\prime \prime}$ & $64^{\circ} 8^{\prime} 51.74^{\prime \prime}$ \\
\hline 86 & VE-091 & $\mid-1660$ & Actiniidae sp. & Isla Cubagua & Las Cabeceras & Nueva Esparta & $10^{\circ} 50^{\prime} 8.40^{\prime \prime}$ & $64^{\circ} 8^{\prime} 51.74^{\prime \prime}$ \\
\hline 87 & $V E-100$ & $\mid-1661$ & Bunodeopsis antillensis & Isla Cubagua & Las Cabeceras & Nueva Esparta & $10^{\circ} 50^{\prime} 8.40^{\prime \prime}$ & $64^{\circ} 8^{\prime} 51.74^{\prime \prime}$ \\
\hline
\end{tabular}


Table 2 Specimens collected during the present study (Continued)

\begin{tabular}{|c|c|c|c|c|c|c|c|c|}
\hline 88 & VE-111 & $1-1662$ & Exaiptasia pallida & Isla Cubagua & La Brea & Nueva Esparta & $10^{\circ} 49^{\prime} 52.97^{\prime \prime}$ & $64^{\circ} 12^{\prime} 36.56^{\prime \prime}$ \\
\hline 89 & VE-114 & |-1663 & Exaiptasia pallida & Isla Cubagua & La Brea & Nueva Esparta & $10^{\circ} 49^{\prime} 52.97^{\prime \prime}$ & $64^{\circ} 12^{\prime} 36.56^{\prime \prime}$ \\
\hline 90 & VE-115 & |-1664 & Calliactis tricolor & Isla Cubagua & La Brea & Nueva Esparta & $10^{\circ} 49^{\prime} 52.97^{\prime \prime}$ & $64^{\circ} 12^{\prime} 36.56^{\prime \prime}$ \\
\hline 91 & VE-116 & |-1665 & Exaiptasia pallida & Isla Cubagua & La Brea & Nueva Esparta & $10^{\circ} 49^{\prime} 52.97^{\prime \prime}$ & $64^{\circ} 12^{\prime} 36.56^{\prime \prime}$ \\
\hline 92 & VE-117 & |-1666 & Exaiptasia pallida & Isla Cubagua & La Brea & Nueva Esparta & $10^{\circ} 49^{\prime} 52.97^{\prime \prime}$ & $64^{\circ} 12^{\prime} 36.56^{\prime \prime}$ \\
\hline 93 & VE-118 & |-1667 & Exaiptasia pallida & Isla Cubagua & La Brea & Nueva Esparta & $10^{\circ} 49^{\prime} 52.97^{\prime \prime}$ & $64^{\circ} 12^{\prime} 36.56^{\prime \prime}$ \\
\hline 94 & VE-119 & |-1668 & Exaiptasia pallida & Isla Cubagua & La Brea & Nueva Esparta & $10^{\circ} 49^{\prime} 52.97^{\prime \prime}$ & $64^{\circ} 12^{\prime} 36.56^{\prime \prime}$ \\
\hline 95 & VE-120 & |-1669 & Exaiptasia pallida & Isla Cubagua & La Brea & Nueva Esparta & $10^{\circ} 49^{\prime} 52.97^{\prime \prime}$ & $64^{\circ} 12^{\prime} 36.56^{\prime \prime}$ \\
\hline 96 & VE-121 & I-1670 & Exaiptasia pallida & Isla Cubagua & La Brea & Nueva Esparta & $10^{\circ} 49^{\prime} 52.97^{\prime \prime}$ & $64^{\circ} 12^{\prime} 36.56^{\prime \prime}$ \\
\hline 97 & VE-123 & |-1671 & Bunodosoma cavernatum & Isla Cubagua & La Brea & Nueva Esparta & $10^{\circ} 49^{\prime} 52.97^{\prime \prime}$ & $64^{\circ} 12^{\prime} 36.56^{\prime \prime}$ \\
\hline 98 & VE-124 & |-1672 & Exaiptasia pallida & Isla Cubagua & La Brea & Nueva Esparta & $10^{\circ} 49^{\prime} 52.97^{\prime \prime}$ & $64^{\circ} 12^{\prime} 36.56^{\prime \prime}$ \\
\hline 99 & VE-125 & |-1673 & Exaiptasia pallida & Isla Cubagua & La Brea & Nueva Esparta & $10^{\circ} 49^{\prime} 52.97^{\prime \prime}$ & $64^{\circ} 12^{\prime} 36.56^{\prime \prime}$ \\
\hline 100 & VE-126 & I-1674 & Exaiptasia pallida & Isla Cubagua & La Brea & Nueva Esparta & $10^{\circ} 49^{\prime} 52.97^{\prime \prime}$ & $64^{\circ} 12^{\prime} 36.56^{\prime \prime}$ \\
\hline 101 & $V E-127$ & |-1675 & Exaiptasia pallida & Isla Cubagua & La Brea & Nueva Esparta & $10^{\circ} 49^{\prime} 52.97^{\prime \prime}$ & $64^{\circ} 12^{\prime} 36.56^{\prime \prime}$ \\
\hline 102 & VE-128 & |-1676 & Exaiptasia pallida & Isla Cubagua & La Brea & Nueva Esparta & $10^{\circ} 49^{\prime} 52.97^{\prime \prime}$ & $64^{\circ} 12^{\prime} 36.56^{\prime \prime}$ \\
\hline 103 & VE-130 & |-1677 & Exaiptasia pallida & Isla Cubagua & La Brea & Nueva Esparta & $10^{\circ} 49^{\prime} 52.97^{\prime \prime}$ & $64^{\circ} 12^{\prime} 36.56^{\prime \prime}$ \\
\hline 104 & VE-132 & |-1678 & Exaiptasia pallida & Isla Cubagua & La Brea & Nueva Esparta & $10^{\circ} 49^{\prime} 52.97^{\prime \prime}$ & $64^{\circ} 12^{\prime} 36.56^{\prime \prime}$ \\
\hline 105 & VE-134 & |-1679 & Exaiptasia pallida & Isla Cubagua & La Brea & Nueva Esparta & $10^{\circ} 49^{\prime} 52.97^{\prime \prime}$ & $64^{\circ} 12^{\prime} 36.56^{\prime \prime}$ \\
\hline 106 & VE-135 & $\mid-1680$ & Anemonia sargassensis & Isla Cubagua & La Brea & Nueva Esparta & $10^{\circ} 49^{\prime} 52.97^{\prime \prime}$ & $64^{\circ} 12^{\prime} 36.56^{\prime \prime}$ \\
\hline 107 & VE-136 & |-1681 & Exaiptasia pallida & Isla Cubagua & La Brea & Nueva Esparta & $10^{\circ} 49^{\prime} 52.97^{\prime \prime}$ & $64^{\circ} 12^{\prime} 36.56^{\prime \prime}$ \\
\hline 108 & VE-137 & |-1682 & Exaiptasia pallida & Isla Cubagua & La Brea & Nueva Esparta & $10^{\circ} 49^{\prime} 52.97^{\prime \prime}$ & $64^{\circ} 12^{\prime} 36.56^{\prime \prime}$ \\
\hline 109 & VE-138 & |-1683 & Exaiptasia pallida & Isla Cubagua & La Brea & Nueva Esparta & $10^{\circ} 49^{\prime} 52.97^{\prime \prime}$ & $64^{\circ} 12^{\prime} 36.56^{\prime \prime}$ \\
\hline 110 & VE-139 & I-1684 & Exaiptasia pallida & Isla Cubagua & La Brea & Nueva Esparta & $10^{\circ} 49^{\prime} 52.97^{\prime \prime}$ & $64^{\circ} 12^{\prime} 36.56^{\prime \prime}$ \\
\hline 111 & VE-140 & |-1685 & Exaiptasia pallida & Isla Cubagua & La Brea & Nueva Esparta & $10^{\circ} 49^{\prime} 52.97^{\prime \prime}$ & $64^{\circ} 12^{\prime} 36.56^{\prime \prime}$ \\
\hline 112 & VE-141 & |-1686 & Actiniidae sp. & Isla Cubagua & La Brea & Nueva Esparta & $10^{\circ} 49^{\prime} 52.97^{\prime \prime}$ & $64^{\circ} 12^{\prime} 36.56^{\prime \prime}$ \\
\hline 113 & VE-142 & |-1687 & Actiniidae sp. & Isla Cubagua & La Brea & Nueva Esparta & $10^{\circ} 49^{\prime} 52.97^{\prime \prime}$ & $64^{\circ} 12^{\prime} 36.56^{\prime \prime}$ \\
\hline 114 & VE-143 & $\mid-1688$ & Actinostella flosculifera & Isla Cubagua & La Brea & Nueva Esparta & $10^{\circ} 49^{\prime} 52.97^{\prime \prime}$ & $64^{\circ} 12^{\prime} 36.56^{\prime \prime}$ \\
\hline 115 & VE-144 & |-1689 & Exaiptasia pallida & Isla Cubagua & La Brea & Nueva Esparta & $10^{\circ} 49^{\prime} 52.97^{\prime \prime}$ & $64^{\circ} 12^{\prime} 36.56^{\prime \prime}$ \\
\hline 116 & VE-145 & |-1690 & Exaiptasia pallida & Isla Cubagua & La Brea & Nueva Esparta & $10^{\circ} 49^{\prime} 52.97^{\prime \prime}$ & $64^{\circ} 12^{\prime} 36.56^{\prime \prime}$ \\
\hline 117 & VE-149 & $\mid-1691$ & Bunodosoma cavernatum & Isla Cubagua & La Brea & Nueva Esparta & $10^{\circ} 49^{\prime} 52.97^{\prime \prime}$ & $64^{\circ} 12^{\prime} 36.56^{\prime \prime}$ \\
\hline 118 & VE-150 & |-1692 & Exaiptasia pallida & Isla Cubagua & La Brea & Nueva Esparta & $10^{\circ} 49^{\prime} 52.97^{\prime \prime}$ & $64^{\circ} 12^{\prime} 36.56^{\prime \prime}$ \\
\hline 119 & VE-153 & |-1693 & Exaiptasia pallida & Isla Cubagua & La Brea & Nueva Esparta & $10^{\circ} 49^{\prime} 52.97^{\prime \prime}$ & $64^{\circ} 12^{\prime} 36.56^{\prime \prime}$ \\
\hline 120 & VE-155 & |-1694 & Anemonia sargassensis & Isla Cubagua & La Brea & Nueva Esparta & $10^{\circ} 49^{\prime} 52.97^{\prime \prime}$ & $64^{\circ} 12^{\prime} 36.56^{\prime \prime}$ \\
\hline 121 & VE-164 & $\mid-1695$ & Exaiptasia pallida & Isla Cubagua & La Brea & Nueva Esparta & $10^{\circ} 49^{\prime} 52.97^{\prime \prime}$ & $64^{\circ} 12^{\prime} 36.56^{\prime \prime}$ \\
\hline 122 & VE-165 & |-1696 & Anemonia sargassansis & La Restinga & Canal de Entrada & Nueva Esparta & $10^{\circ} 58^{\prime} 40.43^{\prime \prime}$ & $64^{\circ} 10^{\prime} 13.84^{\prime \prime}$ \\
\hline 123 & VE-166 & |-1697 & Callactis tricolor & La Restinga & Canal de Entrada & Nueva Esparta & $10^{\circ} 58^{\prime} 40.43^{\prime \prime}$ & $64^{\circ} 10^{\prime} 13.84^{\prime \prime}$ \\
\hline 124 & VE-167 & |-1698 & Bunodeopsis antilliensis & La Restinga & Canal de Entrada & Nueva Esparta & $10^{\circ} 58^{\prime} 40.43^{\prime \prime}$ & $64^{\circ} 10^{\prime} 13.84^{\prime \prime}$ \\
\hline 125 & VE-168 & |-1699 & Anemonia sargassensis & La Restinga & Canal de Entrada & Nueva Esparta & $10^{\circ} 58^{\prime} 40.43^{\prime \prime}$ & $64^{\circ} 10^{\prime} 13.84^{\prime \prime}$ \\
\hline 126 & VE-169 & $\mid-1700$ & Lebrunia neglecta & Mochima & Punta la Cruz & Sucre & $10^{\circ} 23^{\prime} 44.43^{\prime \prime}$ & $64^{\circ} 22^{\prime} 2.16^{\prime \prime}$ \\
\hline 127 & $V E-170$ & $\mid-1701$ & Condylactis gigantea & Mochima & Punta la Cruz & Sucre & $10^{\circ} 23^{\prime} 44.43^{\prime \prime}$ & $64^{\circ} 22^{\prime} 2.16^{\prime \prime}$ \\
\hline 128 & VE-171 & $\mid-1702$ & Actiniidae sp. & Los Roques & Isla Larga & Dependencias Federales & $11^{\circ} 55^{\prime} 40.66^{\prime \prime}$ & $66^{\circ} 45^{\prime} 3.05^{\prime \prime}$ \\
\hline
\end{tabular}




\section{Appendix 2}

Table 3 Examined specimens from MOHBR Collection

\begin{tabular}{|c|c|c|c|c|c|c|c|}
\hline & Code & Previous Identification & Current Identification & State & Locality & Date & Collector \\
\hline 1 & $1-546$ & Actinia 1 & Anemonia sargassensis & Nueva Esparta & $\begin{array}{l}\text { Laguna de Punta de } \\
\text { Piedras, Isla Margarita }\end{array}$ & $23 / 02 / 1995$ & Gutiérrez, J. \\
\hline 2 & $\mid-547$ & Aiptasia pallida & Exaiptasia pallida & Nueva Esparta & $\begin{array}{l}\text { Laguna de Punta de } \\
\text { Piedras, Isla Margarita }\end{array}$ & 16/02/1995 & Gutiérrez, J. \\
\hline 3 & $\mid-881$ & Telmatactis rufa & Telmatactis cricoides & $\begin{array}{l}\text { Dependencias } \\
\text { Federales }\end{array}$ & Isla La Blanquilla & 01/08/1987 & Verginelli, R. \\
\hline 4 & $1-882$ & Stichodactyla helianthus & Stichodactyla helianthus & $\begin{array}{l}\text { Dependencias } \\
\text { Federales }\end{array}$ & Isla de Aves & 01/10/1988 & Sole, G. \\
\hline 5 & I-883 & Stichodactyla helianthus & Stichodactyla helianthus & $\begin{array}{l}\text { Dependencias } \\
\text { Federales }\end{array}$ & Isla La Blanquilla & 26/06/1986 & Piñango, $\mathrm{H}$. \\
\hline 6 & I-884 & Actinostella flosculifera & Actinostella flosculifera & $\begin{array}{l}\text { Dependencias } \\
\text { Federales }\end{array}$ & Isla La Blanquilla & 26/06/1986 & Piñango, $\mathrm{H}$. \\
\hline 7 & $1-885$ & Bartholomea annulata & Bartholomea annulata & Falcón & $\begin{array}{l}\text { Cayo Pescadores, } \\
\text { Morrocoy }\end{array}$ & 01/10/1984 & Agudo, I. \\
\hline 8 & I-886 & Anemonia sargassensis & Anemonia sargassensis & $\begin{array}{l}\text { Dependencias } \\
\text { Federales }\end{array}$ & Isla La Blanquilla & 01/07/1987 & Verginelli, R. \\
\hline 9 & |-887 & Bartholomea annulata & Bartholomea annulata & Falcón & Playa Azul, Morrocoy & $12 / 03 / 1985$ & - \\
\hline 10 & $1-888$ & Stichodactyla helianthus & Stichodactyla helianthus & $\begin{array}{l}\text { Dependencias } \\
\text { Federales }\end{array}$ & Isla La Tortuga & 01/05/1986 & Verginelli, R. \\
\hline 11 & $1-889$ & Bunodeopsis antilliensis & Bunodeopsis antilliensis & Vargas & $\begin{array}{l}\text { Playa Azul, Litoral } \\
\text { Central }\end{array}$ & 13/03/1985 & - \\
\hline 12 & $\mid-891$ & Actinostella flosculifera & Actinostella flosculifera & Falcón & Playa Azul, Morrocoy & 14/03/1985 & - \\
\hline 13 & $1-892$ & Lebrunia danae & Lebrunia neglecta & Falcón & Playa Norte, Morrocoy & $12 / 11 / 1986$ & Agudo, I. \\
\hline 14 & I-893 & Zoanthus proteus & Zoanthus sociatus & Falcón & $\begin{array}{l}\text { Cayo Sombrero, } \\
\text { Morrocoy }\end{array}$ & 09/08/1984 & Agudo, I. \\
\hline 15 & I-894 & Bunodosoma granuliferum & Bunodosoma granuliferum & Vargas & Balneario Camuri Chico & $30 / 11 / 1984$ & Agudo, I. \\
\hline 16 & $1-895$ & Anemonia sargassensis & Anemonia sargassensis & Sucre & $\begin{array}{l}\text { Golfo de Paria, Caño } \\
\text { Guariquén }\end{array}$ & 07/03/1985 & Agudo, I. \\
\hline 17 & $1-896$ & Haliplanella luciae & not identified & Sucre & $\begin{array}{l}\text { Golfo de Paria, Caño } \\
\text { Guariquén }\end{array}$ & $21 / 03 / 1980$ & Verginelli, R. \\
\hline 18 & I-897 & Homostichanthus duerdeni & $\begin{array}{l}\text { Homostichanthus } \\
\text { duerdeni }\end{array}$ & $\begin{array}{l}\text { Dependencias } \\
\text { Federales }\end{array}$ & Isla La Tortuga & 01/05/1986 & Verginelli, $\mathrm{R}$. \\
\hline 19 & $1-898$ & Phymanthus crucifer & Phymanthus crucifer & Vargas & $\begin{array}{l}\text { Playa Azul, Litoral } \\
\text { Central }\end{array}$ & $14 / 03 / 1985$ & - \\
\hline 20 & I-899 & Telmatactis rufa & Telmatactis cricoides & $\begin{array}{l}\text { Dependencias } \\
\text { Federales }\end{array}$ & Isla La Blanquilla & 01/08/1987 & Verginelli, $\mathrm{R}$. \\
\hline 21 & $\mid-900$ & Aiptasia pallida & Exaiptasia pallida & Falcón & $\begin{array}{l}\text { Cayo Pescadores, } \\
\text { Morrocoy }\end{array}$ & 01/10/1984 & $\begin{array}{l}\text { Agudo, I. and } \\
\text { Blondell, S. }\end{array}$ \\
\hline 22 & $\mid-901$ & Bunodeopsis antilliensis & Bunodeopsis antilliensis & $\begin{array}{l}\text { Dependencias } \\
\text { Federales }\end{array}$ & $\begin{array}{l}\text { Archipiélago Los } \\
\text { Testigos, Isla La Iguana }\end{array}$ & $21 / 06 / 1988$ & - \\
\hline 23 & I-904 & Anemonia sargassensis & Anemonia sargassensis & Miranda & Los Totumos & 01/08/1981 & Gil, R. \\
\hline 24 & I-905 & Bunodosoma granuliferum & Bunodosoma granuliferum & Falcón & $\begin{array}{l}\text { Cayo Pescadores, } \\
\text { Morrocoy }\end{array}$ & 01/10/1981 & $\begin{array}{l}\text { Blondell, S. and } \\
\text { Agudo, I. }\end{array}$ \\
\hline 25 & I-906 & Lebrunia danae & Lebrunia neglecta & Sucre & Playa San Luis, Cumaná & 18/06/1982 & Agudo, I. \\
\hline 26 & I-907 & Homostichantus duerdenii & Actinoporus elegans & Vargas & $\begin{array}{l}\text { Playa Azul, Municipio } \\
\text { Vargas, Litoral Central }\end{array}$ & $13 / 03 / 1985$ & - \\
\hline 27 & $\mid-908$ & Condylactis gigantea & Condylactis gigantea & Falcón & $\begin{array}{l}\text { Caño de Manglar, } \\
\text { Morrocoy }\end{array}$ & 06/02/1985 & $\begin{array}{l}\text { López, I. and } \\
\text { Martelo, M. }\end{array}$ \\
\hline 28 & I-909 & Stichodactyla helianthus & Stichodactyla helianthus & Miranda & Los Totumos & 10/06/1982 & Quijano, N. \\
\hline
\end{tabular}


Table 3 Examined specimens from MOHBR Collection (Continued)

\begin{tabular}{|c|c|c|c|c|c|c|c|}
\hline 29 & $\mid-911$ & Condylactis gigantea & Condylactis gigantea & Vargas & $\begin{array}{l}\text { Playa Azul, Litoral } \\
\text { Central }\end{array}$ & $14 / 03 / 1985$ & - \\
\hline 30 & $\mid-912$ & Condylactis gigantea & Condylactis gigantea & Zulia & Isla de Pájaros & $12 / 03 / 1985$ & - \\
\hline 31 & $\mid-913$ & Lebrunia danae & Lebrunia neglecta & $\begin{array}{l}\text { Dependencias } \\
\text { Federales }\end{array}$ & Isla La Blanquilla & - & Agudo, I. \\
\hline 32 & $\mid-914$ & Condylactis gigantea & Condylactis gigantea & Falcón & Boca Seca, Morrocoy & 15/03/1985 & - \\
\hline 33 & $\mid-915$ & Actinostella flosculifera & Actinostella flosculifera & Falcón & $\begin{array}{l}\text { Cayo Boca Seca, } \\
\text { Morrocoy }\end{array}$ & 16/03/1985 & - \\
\hline 34 & $\mid-916$ & Actinostella flosculifera & Actinostella flosculifera & Vargas & $\begin{array}{l}\text { Playa Azul, Litoral } \\
\text { Central }\end{array}$ & 13/03/1985 & - \\
\hline 35 & |-917 & Zoanthus pulchellus & Zoanthus pulchellus & $\begin{array}{l}\text { Dependencias } \\
\text { Federales }\end{array}$ & Isla de Aves & 01/10/1988 & - \\
\hline 36 & $\mid-918$ & Actinostella flosculifera & Actinostella flosculifera & Falcón & $\begin{array}{l}\text { Cayo Sombrero, } \\
\text { Morrocoy }\end{array}$ & $01 / 03 / 1985$ & $\begin{array}{l}\text { Agudo, I. and } \\
\text { Blondell, S. }\end{array}$ \\
\hline 37 & $1-920$ & Condylactis gigantea & Condylactis gigantea & Vargas & $\begin{array}{l}\text { Playa Azul, Litoral } \\
\text { Central }\end{array}$ & $12 / 03 / 1985$ & - \\
\hline 38 & $\mid-921$ & Condylactis gigantea & Condylactis gigantea & Vargas & $\begin{array}{l}\text { Playa Azul, Litoral } \\
\text { Central }\end{array}$ & 13/03/1985 & - \\
\hline 39 & $\mid-923$ & Actinostella flosculifera & Actinostella flosculifera & Vargas & $\begin{array}{l}\text { Playa Azul, Municipio } \\
\text { Vargas, Litoral Central }\end{array}$ & $12 / 03 / 1985$ & - \\
\hline 40 & $\mid-925$ & Condylactis gigantea & Condylactis gigantea & Zulia & Isla de Pájaros & $12 / 03 / 1985$ & - \\
\hline 41 & $1-929$ & Calliactis tricolor & Calliactis tricolor & Sucre & Golfo de Cariaco & - & $\begin{array}{l}\text { Verginelli, R. and } \\
\text { Agudo, I. }\end{array}$ \\
\hline 42 & $1-930$ & Condylactis gigantea & Condylactis gigantea & Vargas & $\begin{array}{l}\text { Playa Azul, Litoral } \\
\text { Central }\end{array}$ & $14 / 03 / 1985$ & - \\
\hline 43 & I-934 & Actinostella flosculifera & Actinostella flosculifera & Falcón & $\begin{array}{l}\text { Cayo Sombrero, } \\
\text { Morrocoy }\end{array}$ & 01/03/1988 & $\begin{array}{l}\text { Agudo, I. and } \\
\text { Blondell, S. }\end{array}$ \\
\hline 44 & |-935 & Condylactis gigantea & Condylactis gigantea & Zulia & Isla de Pájaros & $12 / 03 / 1985$ & - \\
\hline 45 & I-936 & Condylactis gigantea & Condylactis gigantea & Vargas & $\begin{array}{l}\text { Playa Azul, Litoral } \\
\text { Central }\end{array}$ & $14 / 03 / 1985$ & - \\
\hline 46 & $1-938$ & Condylactis gigantea & Condylactis gigantea & Vargas & $\begin{array}{l}\text { Playa Azul, Litoral } \\
\text { Central }\end{array}$ & 13/03/1985 & - \\
\hline 47 & $1-939$ & Condylactis gigantea & Condylactis gigantea & - & - & - & - \\
\hline 48 & |-942 & Stichodactyla helianthus & Stichodactyla helianthus & - & - & $01 / 03 / 1953$ & - \\
\hline 49 & |-943 & Aiptasia pallida & Exaiptasia pallida & Falcón & $\begin{array}{l}\text { Cayo Boca Seca, } \\
\text { Morrocoy }\end{array}$ & $15 / 03 / 1985$ & - \\
\hline 50 & |-944 & Phymanthus crucifer & Phymanthus crucifer & Miranda & Los Totumos & 01/08/1981 & Gil. R. \\
\hline 51 & I-945 & Anemonia sargassensis & Anemonia sargassensis & $\begin{array}{l}\text { Dependencias } \\
\text { Federales }\end{array}$ & Isla La Tortuga & $01 / 05 / 1986$ & Verginelli, R. \\
\hline 52 & I-946 & Lebrunia danae & Lebrunia neglecta & Falcón & $\begin{array}{l}\text { Cayo Pescadores, } \\
\text { Morrocoy }\end{array}$ & 01/10/1984 & Agudo, I. \\
\hline 53 & I-949 & Lebrunia coralligens & Lebrunia coralligens & $\begin{array}{l}\text { Dependencias } \\
\text { Federales }\end{array}$ & Isla La Blanquilla & 01/08/1987 & Verginelli, R. \\
\hline 54 & $\mid-950$ & Palythoa mammillosa & Palythoa caribaeorum & $\begin{array}{l}\text { Dependencias } \\
\text { Federales }\end{array}$ & Isla La Blanquilla & 01/08/1987 & Verginelli, R. \\
\hline 55 & |-953 & Palythoa mammillosa & Palythoa caribaeorum & Falcón & Playa Azul, Morrocoy & $14 / 05 / 1985$ & Agudo, I. \\
\hline 56 & |-954 & Palythoa variabilis & not identified & Falcón & $\begin{array}{l}\text { Cayo Sombrero, } \\
\text { Morrocoy }\end{array}$ & 04/08/1984 & Agudo. I. \\
\hline 57 & |-955 & Isaurus duchassaingi & not identified & Sucre & Laguna de Chacopata & 01/10/1988 & Verginelli, R. \\
\hline 58 & I-956 & Palythoa mammillosa & Palythoa caribaeorum & $\begin{array}{l}\text { Dependencias } \\
\text { Federales }\end{array}$ & Isla La Tortuga & 01/05/1986 & Verginelli, R. \\
\hline 59 & $\mid-957$ & Palythoa caribbeorum & Palythoa caribaeorum & & $\begin{array}{l}\text { Ensenada Penetepe, } \\
\text { Golfo de Cariaco }\end{array}$ & 01/07/1989 & Agudo, I. \\
\hline
\end{tabular}


Table 3 Examined specimens from MOHBR Collection (Continued)

\begin{tabular}{|c|c|c|c|c|c|c|c|}
\hline 60 & $\mid-961$ & Zoanthus sociatus & Zoanthus sociatus & $\begin{array}{l}\text { Dependencias } \\
\text { Federales }\end{array}$ & Isla La Blanquilla & 01/08/1987 & Verginelli, $\mathrm{R}$. \\
\hline 61 & $\mid-978$ & Bartholomea annulata & Bartholomea annulata & $\begin{array}{l}\text { Dependencias } \\
\text { Federales }\end{array}$ & $\begin{array}{l}\text { Gran Roque, Los } \\
\text { Roques }\end{array}$ & 19/04/1954 & - \\
\hline 62 & I-994 & Phymanthus crucifer & Phymanthus crucifer & Falcón & $\begin{array}{l}\text { Parque Nacional } \\
\text { Morrocoy }\end{array}$ & 25/03/1973 & García, C. \\
\hline 63 & $\mid-1151$ & Actinostella flosculifera & Actinostella flosculifera & Nueva Esparta & Isla Cubagua & $14 / 11 / 2002$ & Capelo, J. \\
\hline 64 & $\mid-1152$ & Stichodactyla helianthus & Stichodactyla helianthus & Nueva Esparta & $\begin{array}{l}\text { Laguna de Punta de } \\
\text { Piedras, Isla Margarita }\end{array}$ & 23/02/1989 & Velásquez, Y. \\
\hline 65 & $\mid-1155$ & Stichodactyla helianthus & Stichodactyla helianthus & $\begin{array}{l}\text { Dependencias } \\
\text { Federales }\end{array}$ & $\begin{array}{l}\text { Isla La Blanquilla, } \\
\text { Caronton }\end{array}$ & 13/03/1988 & - \\
\hline 66 & $\mid-1192$ & Bunodosoma cavernata & Bunodosoma cavernatum & Nueva Esparta & $\begin{array}{l}\text { Laguna de La Restinga, } \\
\text { Isla Margarita }\end{array}$ & $20 / 01 / 2011$ & $\begin{array}{l}\text { Carrasquel, M. and } \\
\text { Velásquez, M. }\end{array}$ \\
\hline 67 & $\mid-1193$ & Phyllactis praetexta & Actinostella flosculifera & Nueva Esparta & $\begin{array}{l}\text { Laguna de La Restinga, } \\
\text { Isla Margarita }\end{array}$ & $20 / 01 / 2011$ & $\begin{array}{l}\text { Carrasquel, M. and } \\
\text { Velásquez, M. }\end{array}$ \\
\hline 68 & ।-1194 & Stichodactyla helianthus & Stichodactyla helianthus & Nueva Esparta & $\begin{array}{l}\text { Laguna de La Restinga, } \\
\text { Isla Margarita }\end{array}$ & $20 / 01 / 2011$ & $\begin{array}{l}\text { Carrasquel, M. and } \\
\text { Velásquez, M. }\end{array}$ \\
\hline 69 & $\mid-1197$ & Actinostella flosculifera & Actinostella flosculifera & Nueva Esparta & $\begin{array}{l}\text { Laguna de La Restinga, } \\
\text { Isla Margarita }\end{array}$ & $27 / 06 / 2012$ & Carrasquel, M. \\
\hline 70 & $\mid-1198$ & Anemonia sargassensis & Anemonia sargassensis & Nueva Esparta & $\begin{array}{l}\text { Laguna de La Restinga, } \\
\text { Isla Margarita }\end{array}$ & $24 / 05 / 2012$ & Carrasquel, M. \\
\hline 71 & $\mid-1199$ & Aiptasia pallida & Exaiptasia pallida & Nueva Esparta & Isla Cubagua & $25 / 03 / 2012$ & $\begin{array}{l}\text { Carrasquel, M. } \\
\text { and Méndez, E. }\end{array}$ \\
\hline 72 & $\mid-1200$ & Actinostella flosculifera & Actinostella flosculifera & Nueva Esparta & $\begin{array}{l}\text { Laguna de La Restinga, } \\
\text { Isla Margarita }\end{array}$ & $30 / 03 / 2009$ & Carrasquel, M. \\
\hline 73 & $\mid-1201$ & Stichodactyla helianthus & Stichodactyla helianthus & Nueva Esparta & $\begin{array}{l}\text { Laguna de La Restinga, } \\
\text { Isla Margarita }\end{array}$ & $31 / 04 / 2012$ & Carrasquel, M. \\
\hline 74 & $\mid-1204$ & Calliactis tricolor & Calliactis tricolor & Nueva Esparta & $\begin{array}{l}\text { Bajo Manzanillo, Isla } \\
\text { Margarita }\end{array}$ & $28 / 06 / 2012$ & López, R. \\
\hline 75 & $\mid-1205$ & Anemonia sargassensis & Anemonia sargassensis & Nueva Esparta & $\begin{array}{l}\text { Laguna de La Restinga, } \\
\text { Isla Margarita }\end{array}$ & 07/06/2012 & Carrasquel, M. \\
\hline 76 & $\mid-1206$ & Bunodeopsis antilliensis & Bunodeopsis antilliensis & Nueva Esparta & $\begin{array}{l}\text { Laguna de La Restinga, } \\
\text { Isla Margarita }\end{array}$ & $27 / 06 / 2012$ & Carrasquel, M. \\
\hline 77 & $\mid-1207$ & Stichodactyla helianthus & Stichodactyla helianthus & Nueva Esparta & Isla Cubagua & $24 / 07 / 2012$ & $\begin{array}{l}\text { Carrasquel, M. } \\
\text { and Méndez, E. }\end{array}$ \\
\hline 78 & $\mid-1208$ & Anemonia sargassensis & Anemonia sargassensis & Nueva Esparta & Isla Cubagua & $24 / 07 / 2012$ & $\begin{array}{l}\text { Carrasquel, M. } \\
\text { and Méndez, E. }\end{array}$ \\
\hline 79 & $\mid-1209$ & Lebrunia danae & Lebrunia neglecta & Nueva Esparta & Isla Cubagua & $24 / 07 / 2012$ & $\begin{array}{l}\text { Carrasquel, M. } \\
\text { and Méndez, E. }\end{array}$ \\
\hline 80 & $\mid-1210$ & Bartholomea annulata & Bartholomea annulata & Nueva Esparta & Isla Cubagua & $24 / 07 / 2012$ & $\begin{array}{l}\text { Carrasquel, M. } \\
\text { and Méndez, E. }\end{array}$ \\
\hline 81 & $\mid-1211$ & Aiptasia pallida & Exaiptasia pallida & Nueva Esparta & Isla Cubagua & $24 / 07 / 2012$ & $\begin{array}{l}\text { Carrasquel, M. } \\
\text { and Méndez, E. }\end{array}$ \\
\hline 82 & $\mid-1212$ & Phymanthus crucifer & Phymanthus crucifer & Nueva Esparta & Isla Cubagua & $24 / 07 / 2012$ & $\begin{array}{l}\text { Carrasquel, M. } \\
\text { and Méndez, E. }\end{array}$ \\
\hline 83 & $\mid-1213$ & Phymanthus crucifer & Phymanthus crucifer & Nueva Esparta & $\begin{array}{l}\text { Laguna de Punta de } \\
\text { Piedras, Isla Margarita }\end{array}$ & 23/02/1989 & Velásquez, Y. \\
\hline 84 & $\mid-1214$ & Aiptasia pallida & Exaiptasia pallida & Vargas & $\begin{array}{l}\text { Playa Azul, Litoral } \\
\text { Central }\end{array}$ & 13/03/1985 & - \\
\hline
\end{tabular}




\section{Abbreviations}

MOHBR: Museo Oceanológico Hermano Beningo Román.

\section{Competing interests}

The authors declare that they have no competing interests.

\section{Authors' contributions}

$R G, N S, E G, C H, A C$ and JC designed and coordinated the study and the collection of data, and drafted the manuscript. RG, NS, EG, CH, GC, EM, CL, $M R, I V, S P, A C$, and JC participated in the collection of specimens, the taxonomic identification of sea anemones species, and the revision of the specimens vouchered at the Museo Oceanológico Hermano Benigno Román. All authors read and approved the final manuscript.

\section{Acknowledgements}

This work represent the results of a workshop on taxonomy of sea anemones in Venezuela, celebrated at Escuela de Ciencias Aplicadas del Mar, Universidad de Oriente Núcleo Nueva Esparta, Venezuela. Esteban Agudo, Pedro Cádiz, Mariana Cover, Alejandra Hernández, Francoise Cavada, Yuruani Fuentes, Claudina Mata, Cecilia Gómez, Verónica Gómez, Beatríz Ríos, Daniela Arteaga, Pablo Aguilar, Gianco Angelozzi, Luisamary Guia, and Fernanda González helped during field and lab work. The curator the collection of the MOHBR JP Capello is thanked for his kind assistance during the revision of specimens. Commentaries of James Reimer, Fabián Acuña and Agustín Garese improve this manuscript. The first author is grateful to the Programa de Becas Postdoctorales of the Comisión Nacional de Ciencia y Tecnología (CONACyT, grant 232318). This work was partially supported by the project CONACYT-SEMARNAT (to N.S., grant 108285) and DGAPA-PAPIME-UNAM (to N.S., grant PE207210).

\section{Author details}

${ }^{1}$ Departamento de Ciencias de la Sustentabilidad, El Colegio de la Frontera Sur (ECOSUR), Laboratorio de Biodiversidad y Cambio Climático, Avenida Rancho Polígono 2A, Ciudad Industrial, Lerma Campeche, Campeche C.P. 24500, México. ${ }^{2}$ Laboratorio de Biología de Cnidarios, Facultad de Ciencias Exactas y Naturales, Universidad Nacional de Mar del Plata, Funes 3250, Mar del Plata C.P. 7600, Argentina. ${ }^{3}$ Unidad Multidisciplinaria de Docencia e Investigación en Sisal (UMDI-Sisal), Facultad de Ciencias, Universidad Nacional Autónoma de México (UNAM), Puerto de Abrigo, Sisal, Yucatán C.P. 97356, Mexico. ${ }^{4}$ Escuela de Ciencias Aplicadas del Mar, Universidad de Oriente, Núcleo Nueva Esparta, Boca de Río, Isla de Margarita, Venezuela. ${ }^{5}$ Departamento de Ciencias, Universidad de Oriente, Núcleo Nueva Esparta, Boca de Río, Isla de Margarita, Venezuela. Institut Français de Recherche pour l'Exploitation de la Mer, Laboratoire d'Environnement Profond, Plouzané, France. ${ }^{7}$ Instituto de Zoología Tropical, Escuela de Biología, Facultad de Ciencias, Universidad Central de Venezuela, C.P. 47058, Caracas 1041, Venezuela. ${ }^{8}$ Departamento de Estudios Ambientales, Laboratorio de Ecología Experimental, Universidad Simón Bolívar, A.P. 89000, Caracas, Sartenejas 1080, Venezuela.

\section{Received: 9 February 2016 Accepted: 23 February 2016}

\section{Published online: 22 March 2016}

\section{References}

Acosta A, Casas M, Vargas CA, Camacho JE. Lista de Zoantharia (Cnidaria: Anthozoa) del Caribe y de Colombia. Biota Colomb. 2005;6:147-61.

Agudo I. Contribución al conocimiento de la actinofauna de Venezuela (Anthozoa: Ceriantipatharia y Zoantharia). Caracas: Proyecto Taxonomía, Ecología, Zoogeografía y Toxicología de la Actinofauna de Venezuela; 1987.

Alves-Santos ME, Kitahara MV, Lindner A, Reimer JD. Overview of the order Zoantharia (Cnidaria: Anthozoa) in Brazil. Mar Biodivers. 2015. doi: 10.1007/ s12526-015-0396-7.

Andres A. Prodromus neapolitanae faunae addito generalis actiniarium bibliographie catalogo. Mitteilungen aus der Zool Stn zy Neapel. 1881;2:305-9.

Andres A. Le Attinie. Roma: Coi Tipi der Salviucci; 1883.

Atoda K. The development of the sea anemone, Diadumene luciae, reproduced by the pedal laceration. Sci Reports Tohoku Univ. 1954;20:123-9.

Bastidas C, Bone D. Competitive strategies between Palythoa caribaeorum and Zoanthus sociatus (Cnidaria: Anthozoa) at a reef flat environment in Venezuela. Bull Mar Sci. 1996;59:543-55.
Belém MJC. Anatomy and biology of Bunodosoma caissarum Correa, 1964 (Cnidaria, Anthozoa, Actiniidae). I. Systematic position and revision of morphology and microanatomy. An Acad Bras Cienc. 1987;60:365-75.

Belém MJC, Preslercravo J. Contribuições ao conhecimento da fauna de cnidarios do Espírito Santo, Brasil I - Considerações sóbre Actiniaria do Município de Aracruz, E. S. Bol do Mus Biol Prof Mello Leitao. 1973;80:1-14.

Belém MJC, Schlenz E. First records of an Isophelliidae (Cnidaria, Actiniaria) in Brazil, with the description of Telmatactis rufa (Verrill, 1900) and observations on its asexual reproduction. An da Acad Bras Ciências (Rio Janeiro). 1989;61:343-53.

Beneti JS, Stampar SN, Maronna MM, Morandini AC, Silveira FL. A new species of Diadumene (Actiniaria: Diadumenidae) from the subtropical coast of Brazil. Zootaxa. 2015;4021:156-68. doi:10.11646/zootaxa.4021.1.6.

Bitter-Soto R. Benthic communities associated to Thalassia testudinum (Hydrocharitaceae) at three localities of Morrocoy National Park, Venezuela. Rev Biol Trop Biol Trop. 1999;47:443-52.

Bosc LAG. Historie Naturalle des Vers. Paris: Chez Deterville; 1802.

Briggs KB, Richardson MD, Young DK. The classification and structure of megafaunal assemblages in the Venezuela Basin, Caribbean Sea. J Mar Res. 1996:54:705-30. doi:10.1357/0022240963213736.

Cairns S, den Hartog JC, Arneson C. Class Anthozoa (Corals, Anemones). In: Sterrer W, Schoepfer-Sterrer C, editors. Marine Fauna and Flora of Bermuda. New York: John Wiley and Sons; 1986. p. 159-94.

Carlgren O. Studien über nordische Actinien. K Sven Vetenskapsakademiens Handl. 1893;25:1-148.

Carlgren O. Jahresbeichte für 1889, 1890, und 1891 über die Anthozoen. Arch für Naturgeschichte. 1895;61:235-98.

Carlgren O. Ostafrikanische Actinien. Gesammelt von Hern Dr. F. Stuhlmann 1888 und 1889. Mitth aus dem Naturhistorischen Museum. 1900;17:21-144.

Carlgren O. Actiniaria from New Zealand and its Subantarctic Island. Vidensk Meddelelser fra Dansk Naturhistorisk Foren. 1924a;77:179-261.

Carlgren O. On Boloceroides, Bunodeopsis and their supposed allied genera. Ark für Zool. 1924b;17:1-20.

Carlgren O. On some Ceriantharia. Ark für Zool. 1931;23:1-10.

Carlgren O. Die Ceriantharien, Zoantharien und Actiniarien des arktischen Gebietes. In: Römer F, Schaudinn F, Brauer A, Arndt W, editors. Eine Zusammenstellung der arktischen Tierformen mit Bes. Berücksichtigung des Spitzbergen-Gebietes auf Grund der Ergebnisse der Dtsch. Exped. das Nördliche Eismeer im Jahre 1898. Jena: Gustav Fischer; 1932. p. 255-66.

Carlgren O. A contribution to the knowledge of the structure and distribution of the cnidae in the Anthozoa. K Fysiogr Sälskapets Handl. 1940;51:1-62.

Carlgren O. Papers from Dr. Th. Mortensen's Pacific Expedition 1914-16. LXX. The Actiniaria and Zoantharia of St. Helena. Vidensk Meddelelser fra Dansk Naturhistorisk Foren. 1941;105:1-20.

Carlgren O. East-Asiatic Corallimorpharia and Actiniaria. K Sven Vetenskaps Akad Handl Ser. 1943;20:1-43.

Carlgren O. A survey of the Ptychodactiaria, Corallimorpharia and Actiniaria. K Sven Vetenskapsakademiens Handl. 1949;1:1-121.

Carlgren O. Actiniaria from North America. Ark für Zool. 1952;3:373-90.

Carlgren O, Hedgpeth JW. Actiniaria, Zoantharia and Ceriantharia from shallow water in the northwestern Gulf of Mexico. Publ Inst Mar Sci Univ Texas. 1952;2:143-72.

Carrasquel MG. Inventario de anémonas (Cnidaria: Anthozoa: Actiniaria) asociadas al sistema de manglar del Parque Nacional Laguna de la Restinga, Isla de Margarita. Nueva Esparta: Universidad de Oriente; 2012

Cary LR. A contribution to the fauna of the coast of Louisiana. Gulf Biol Stn Bull. 1906:6:50-9.

Chen C, Soong K, Chen CA. The smallest oocytes among broadcast-spawning actiniarians and a unique lunar reproductive cycle in a unisexual population of the sea anemone, Aiptasia pulchella (Anthozoa: Actiniaria). Zool Stud. 2008:47:37-45.

Conde JE, Carmona-Suárez C. Ecosistemas marino-costeros. In: Aguilera M, Azócar A, González-Jiménez E, editors. Biodiversidad en Venezuela. Caracas: Fundación Polar; 2003. p. 863-83.

Corrêa DD. Corallimorpharia e Actiniaria do Atlantico Oeste Tropical. Brasil: Universidade de São Paulo, São Paulo; 1964.

Corrêa DD. Sobre anémonas-do-mar (Actiniaria) do Brasil. Boletím Zool e Biol. 1973;30:457-68.

Crocker LA, Reiswig HM. Host specificity in sponge-encrusting Zoanthidea (Anthozoa: Zoantharia) of Barbados, West Indies. Mar Biol. 1981;65:231-6.

Crowther A. Character evolution in light of phylogenetic analysis and taxonomic revision of the zooxanthellate sea anemone families Thalassianthidae and Aliciidae. Kansas: University of Kansas; 2013. 
Cutress BD, Cutress CE. De valkuilanemoon (Actinoporus elegans Duchassaing, 1850). Het Aquarium Maandbl voor Aquarium, Terr en Insektariumkd. 1976;46:310-3.

Daly $M$. The anatomy, terminology, and homology of acrorhagi and pseudoacrorhagi in sea anemones. Zool Verh. 2003;345:89-101.

Daly M, den Hartog JC. Taxonomy, circumscription, and usage in Anthopleura (Cnidaria: Anthozoa: Actiniaria) from the Gulf of Mexico and Caribbean. Bull Mar Sci. 2004;74:401-21.

Dana JD. Zoophytes. Volume VII of the United States Exploring Expedition during the years 1838, 1839, 1840, 1841, 1842, under the command of Charles Wilkes, U.S.N. Philadelphia: Lea and Blanchard; 1846.

Delage Y, Hirouard E. Traité de Zoologie Concreté. Les Coelenterates. Paris: Reinwald; 1901

Delle Chiaje S. Descrizione e notomia degli animali invertebrati della Sicilia Citeriore osservati vivi negli anni 1822-1830. Napoli: C. Batelli e Comp; 1841.

Den Hartog JC. Descriptions of two new Ceriantharia from the Caribbean Region, Pachycerianthus curacaoensus n.sp. and Arachnanthus nocturnus n.sp., with a discussion of the cnidom and of the classification of the Ceriantharia. Zool Meded. 1977;M51:211-48.

den Hartog JC. Caribbean shallow water Corallimorpharia. Zool Verh. 1980;176:1-83

den Hartog JC, Ocaña O, Brito A. Corallimorpharia collected during the CANCAP expeditions (1976-1986) in the south-eastern part of the North Atlantic. Zool Verh. 1993;282:1-76.

Deshayes GP, Milne-Edwards H. Revue et augmentée de notes présentant les faits nouveaux dont la science s'est enrichie jusqu'a ce jour. In: Hist. Nat. des Animaux sans Vertébres, Présentant les caractères généraux Part. ces animaux, leur Distrib. leurs classes, leurs Fam. leurs genres, la Cit. des Princ. espèces qui s'y Rapp. 2nd ed. Paris: J.B. Baillière; 1840.

Doumenc D. Notes sur les actinies de Polynésie Française. Cah du Pacifique. 1973;17:173-204.

Duchassaing P. Animaux Radiaires des Antilles. Paris: Plon Fréres; 1850.

Duchassaing P. Revue des Zoophytes et des Spongiaires des Antilles. Paris: Chez Victor Masson et Fils; 1870.

Duchassaing P, Michelotti G. Mémoire sur les Coralliaires des Antilles. Turin: Imprimerie Royale; 1860.

Duchassaing $P$, Michelotti G. Supplément au mémoire sur les Coralliaires des Antilles. Turin: Imprimerie Royale; 1864a.

Duchassaing P, Michelotti G. Spongiaires de la mer Caraïbe. Natuurkundige Verh van Hollandsche Maatsch der Wet te Haarlem. 1864b;21:1-124.

Duchassaing P, Michelotti J. Supplément au Mémoire sur les Coralliaires des Antilles. Mem R Accad delle Sci di Torino. 1866;8:97-206.

Duerden JE. On the genus Alicia (Cladactis), with an anatomical description of $A$ costae, Panc. Ann Mag Nat Hist. 1895;15:213-8.

Duerden JE. The actiniarian family Aliciidae. Ann Mag Nat Hist. 1897;20:1-15.

Duerden JE. The Actiniaria around Jamaica. J Inst Jamaica. 1898a;2:449-65.

Duerden JE. Jamaican Actiniaria. Part I. - Zoanthideæ. Sci Trans R Dublin Soc. 1898b;6:329-84.

Duerden JE. Jamaican Actiniaria. Part II. Stichodactylinæ and Zoantheæ. Sci Trans R Dublin Soc. 1900;7:133-208.

Duerden JE. Report of the Actinians of Porto Rico (Investigations of the aquatic resources and fisheries of Porto Rico by the U. S. Fish Commission Steamer Fish Hawk in 1899). Bull U S Fish Comm. 1902;20:323-74.

Dunn DF. The clownfish sea anemones: Stichodactylidae (Coelenterata: Actiniaria) and other sea anemones symbiotic with pomacentrid fishes.le. Trans Am Philos Soc. 1981;71:1-115.

Ehrenberg CG. Beiträge zur physiologischen Kenntniss der Corallenthiere im allgemeinen, und besonders des rothen Meeres, nebst einem Versuche zur physiologischen Systematik derselben. Abhandlungen der Königlichen Akad der Wissenschaften zu Berlin. 1834;1:225-380.

Ellis J. An account of the Actinia sociata, or clustered animal-flower, lately found on the sea-coast of the new-ceded islands. Philos Trans R Soc London. 1768:57:428-37.

Ellis J, Solander D. The Natural History of Many Curious and Uncommon Zoophytes, Collected from Various Parts of the Globe. London: Benjamin White and Son; 1786.

Fautin DG. Corallimorphus niwa new species (Cnidaria: Anthozoa), New Zealand members of Corallimorphus, and redefinition of Corallimorphidae and its members. Zootaxa. 2011:49:37-49.

Fautin DG. Hexacorallians of the World. 2013. http://geoportal.kgs.ku.edu/ hexacoral/anemone2/index.cfm. Accessed 28 Jan 2016.

Fautin DG, Daly M. Actiniaria, Corallimorpharia, and Zoanthidea (Cnidaria: Anthozoa) of the Gulf of Mexico. In: Felder D, Camp D, editors. Gulf of
Mexico. Origens, Waters and Biota. 1st ed. Texas: Texas A\&M University Press, College Station; 2009. p. 349-64.

Fisher E. Redescription of the sea anemone Bunodeopsis pelagica. Stud Fauna Curaçao other Caribb Islands. 1976;50:103-19.

González-Muñoz R, Simões N, Sanchez-Rodríguez J, Rodríguez E, Segura-Puertas L. First inventory of sea anemones (Cnidaria: Actiniaria) of the Mexican Caribbean. Zootaxa. 2012;3556:1-38.

González-Muñoz R, Simões N, Tello-Musi JL, Rodríguez E. Sea anemones (Cnidaria, Anthozoa, Actiniaria) from coral reefs in the southern Gulf of Mexico. Zookeys. 2013;106:77-106. doi:10.3897/zookeys.341.5816.

González-Muñoz R, Simões N, Mascaró M, Tello-Musi JL, Brugler MR, Rodríguez E. Morphological and molecular variability of the sea anemone Phymanthus crucifer (Cnidaria, Anthozoa, Actiniaria, Actinoidea). J Mar Biol Assoc United Kingdom. 2015;95:69-79. doi:10.1017/S0025315414000988.

Gosse PH. A History of the British Sea-Anemones and Corals. London: Van Voorts; 1860.

Grajales A, Rodríguez E. Morphological revision of the genus Aiptasia and the family Aiptasiidae (Cnidaria, Actiniaria, Metridioidea). Zootaxa. 2014;3826:55-100.

Gravier C. Sur un type nouveau d'actinie de l'ile San Thomé (Golfe de Guinée). Bull du Muséum Natl d'Histoire Nat. 1916;22:234-6.

Gravier C. Note préliminaire sur les hexactiniaires recueillis au cours des croisières de la Princesse-Alice et de l'Hirondelle de 1888 à 1913 inclusivement. Bull I'Institut Océanographique. 1918;346:1-24.

Gusmão LC. Systematics and evolution of sea anemones (Cnidaria: Actiniaria: Hormathiidae) symbiotic with hermit crabs. USA: The Ohio State University; 2010.

Haddon AC. The Actiniaria of Torres Straits. Sci Trans R Dublin Soc. 1898;6:393-520.

Haddon AC, Shackleton AM. A revision of the British actiniae. Part II: The Zoantheae. Sci Trans R Dublin Soc. 1891;4:609-72.

Hanlon RT, Hixon RF, Smith DG. Behavioral associations of seven West Indian reef fishes with sea anemones at Bonaire. Netherland Antilles Bull Mar Sci. 1983;33:928-34

Hargitt CW. Notes on a few coelenterates of Woods Hole. Biol Bull. 1908;14:95-120.

Hargitt CW. Cradactis variabilis: an apparently new Tortugan actinian. Pap from Tortugas Lab Carnegie Inst Washingt. 1911;3:51-3.

Hedgpeth JW. Anthozoa: the anemones. Fish Bull Fish Wildl Serv. 1954;55:285-90.

Henríquez YA, Palacios ME. Distribución del antozoo Stichodactyla helianthus en un arrecife franjeante de Isla Larga, Parque Nacional San Esteban, Estado Carabobo, Venezuela. Faraute. 2008;3:5-16.

Hertwig R. Report on the Actiniaria dredge by H.M.S. Challenger during the years 1873-1876. Sci Res Voy HMS Challenger Zool. 1882;6:1-136.

Hertwig R. Report on the Actiniaria dredged by H. M. S. Challenger during the years 1873-1876 (Supplement). Rep Sci Results Voyag H M S Chall Dur years 1873-76. 1888;26:1-56.

Higgin T. Description of some Sponges obtained during a Cruise of the Steam-Yacht "Argo" in the Caribbean and neighbouring Seas. Ann Mag Nat Hist. 1877;19:291-9.

ICZN. International Code of Zoological Nomenclature, 4th ed. London: International Trust for Zoological Nomenclature; 1999.

Knowlton N, Keller BD. Two more siblings species of alpheid shrimps associated with the Caribbean sea anemones Bartholomea annulata and Heteractis lucida. Bull Mar Sci. 1985:37:893-904.

Lamarck JBP. Sur les polypiers empâtés. Suite du mémoire intitulé: Sur les Polypiers empâtés. Suite des éponges. Ann du Muséum Natl d'histoire Nat Paris. 1814;20:370-86.

Le Sueur CA. Observations on several species of the genus Actinia; ilustrated by figures. J Acad Sci Philadelphia. 1817;1:149-54. 169-189.

Lewis JB. The fauna of rocky shores of Barbados, West Indies. Can J Zool. 1960;38:391-435.

Liñero-Arana I, González L. Hábitos alimenticios y aspectos poblacionales de Scolanthus curacaoensis (Pax, 1924) (Anthozoa: Actiniaria) en la laguna de Chacopata, Venezuela. Boletín del Inst Ocean Venez. 2008;47:41-5.

Losada F, Pauls SM. Cnidarios. In: Aguilera M, Azócar A, González-Jiménez E, editors. Biodiversidad en Venezuela. Caracas: Fundación Polar; 2003. p. 228-41.

Losada F, Martín A, Feragotto W, Alamo C. Interacciones biológicas en el canal de toma de la Planta Termoeléctrica del Centro en Punta Moron, Venezuela. Ecotropicos. 1988;1:55-70.

Marshall W. Spongiologische Beiträge. Leipzig: Festschrift; 1892.

McMurrich JP. Notes on the fauna of Beaufort, North Carolina. Stud Biol Lab Johns Hopkins Univ. 1887;4:55-63.

McMurrich JP. A contribution to the actinology of the Bermuda. Proc Acad Nat Sci Philadelphia. 1889a:102-126. 
McMurrich JP. The Actiniaria of the Bahama Islands, W.I. J Morphol. 1889b;3:1-18. McMurrich JP. Report on the Actiniæ collected by the United States Commision Steamer Albatross during the winter of 1887-1888. Proc United States Natl Museum. 1893;16:119-216.

McMurrich JP. Report on the Actiniaria collected by the Bahama Expedition of the State University of lowa, 1893. Bull from Lab Nat Hist State Univ lowa. 1898:4:225-49.

McMurrich JP. A revision of the Duchassaing and Michelotti actinian types in the Museum of Natural History, Turin. Bolletino del Musei di Zool ed Anat Comp. 1905;494:1-23.

McMurrich JP. The genus Arachnactis. J Exp Zool. 1910;9:159-68.

Milne-Edwards H. Historie Naturelle des Coralliaires ou Polypes Proprement Dits, vol. 1. Paris: Librairie Encyclopédique de Roret; 1857.

Miloslavich P, Klein E, Martin A, Bastidas C, Marín B, Spiniello P. Marine Biodiversity Reviews: Venezuela. In: Miloslavich P, Klein E, editors. Caribbean Marine Biodiversity: the known and the unknown. Lancaster: Destech Publications; 2005. p. 109-36.

Molodtsova T. Fauna ceriantariy atlanticheskogo okeana I sostav roda Cerianthus mirovoy fauny. Aftoreferat na soiskanie uchenoy stepeni kandidata biologicheskih nauk. Moscow: Dialog-MGU; 2000.

Molodtsova T. On Isarachnanthus from Central Atlantic and Caribbean region with notes on Isarachnanthus lobiancoi (Carlgren, 1912). Zool Verh. 2003;345: 249-55.

Molodtsova T. Ceriantharia (Cnidaria) of the Gulf of Mexico. In: Felder D, Camp D, editors. Gulf of Mexico, Origins, Waters and Biota. 1st ed. Texas: Texas A\&M University Press, College Station; 2009. p. 365-7.

Ocaña O, den Hartog JC. A catalogue of Actiniaria and Corallimorpharia from the Canary Islands and from Madeira. Arquipélago Life Mar Sci. 2002;19A:33-54.

Ocaña O, Moro L, Ortea J, Espinosa J, Caballer M. Visual Guide of the marine biodiversity of Guanahacabibes.I - Anemones (Anthozoa: Actiniaria, Corallimorpharia, Ceriantharia \& Zoanthidea). Avicennia. 2007;19:133-42.

Pang RK. The systematics of some Jamaican excavating sponges (Porifera). Postilla. 1973;161:1-75.

Pax F. Anthozoa. Die Aktinienfauna Westafrikas. Denkschriften der MedizinischNaturwissenschafttlichen Gesellschaft. 1908;13:463-504.

Pax F. Studien an westindischen Actinien. Zool Jahrbücher. 1910;2:157-330.

Pax F. Actiniarien, Zoantharien und Ceriantharien von Curaçao. K Zool Genoot Nat Artis Magistra. 1924;23:93-122.

Pax F, Müller I. Zoantharien des zoologischen museums in Genua. Ann del Mus Civ di Stor Nat Giacomo Doria. 1957:69:19-30.

Perrier E. Sur un nouveau Crinoïde fixé, le Democrinus Parfaiti, provenant des dragages du Travailleur. Comptes Rendus Académie des Sci. 1883;96:450-2.

Pires DO, Castro CB, Migotto AE, Marques AC. Cnidários Bentónicos do arquipélago de Fernando de Noronha, Brasil. Bol do Mus Nac. 1992;354:1-21.

Rafinesque CS. Analyse de la Nature ou Tableau de I'Univers et des Corps Organisés. Palerme: Rafinesque, C.S; 1815.

Rapp W. Ueber die Polypen im Allgemeinen und die Actinien. Weimar: Grolsherzogl; 1829.

Reimer JD, Sinniger F, Fujiwara Y, Hirano S, Maruyama T. Morphological and molecular characterisation of *Abyssoanthus nankaiensis*, a new family, new genus and new species of deep-sea zoanthid (Anthozoa: Hexacorallia: Zoantharia) from a northwest Pacific methane cold seep. Invertebr Syst. 2007;21:255-62.

Reimer JD, Hirose M, Wirtz P. Zoanthids of the Cape Verde Islands and their symbionts: previously unexamined diversity in the Northeastern Atlantic. Contrib to Zool. 2010;79:147-63.

Reimer JD, Foord C, Irei Y. Species Diversity of Shallow Water Zoanthids (Cnidaria: Anthozoa: Hexacorallia) in Florida. J Mar Biol. 2012;1-14. doi: 10.1155/2012/ 856079.

Riemann Z. On some abyssal sea anemones of the North Atlantic (Actiniaria; Hormathiidae). Mitteilungen aus dem Hambg Zool Museum und Inst. 1986; 83:7-29.

Rodríguez E, Barbeitos MS, Brugler MR, Crowley LM, Grajales A, Gusmão L, et al. Hidden among sea anemones: The first comprehensive phylogenetic reconstruction of the order Actiniaria (Cnidaria, Anthozoa, Hexacorallia) reveals a novel group of hexacorals. PLoS One. 2014; doi: 10.1371/journal. pone.0096998.

Roule L. Sur les genres Palythoa et Epizoanthus. Comptes Rendus Hebd des Séances l'Académie des Sci Paris. 1900;131:279-81.

Ryland JS, Lancaster JE. Revision of methods for separating species of Protopalythoa (Hexacorallia:Zoanthidea) in the tropical West Pacific. Invertebr Syst. 2003;17:407-28. doi:10.1071/IS02008.
Schlenz E, Belém MJC. Phyllactis correae n. sp. (Cnidaria, Actiniaria, Actiniidae) from Atol das Rocas, Brazil, with notes on Phyllactis flosculifera (Le Sueur, 1817). Bol Zool Univ Sãu Paulo. 1992;12:91-117.

Schmidt O. Grundzüge einer Spongien-Fauna des atlantischen Gebietes. Leipzig: Engelmann; 1870.

Sebens KP. Intertidal distribution of Zoanthids on the Caribbean coast of Panama: Effects of predation and desiccation. Bull Mar Sci. 1982;32(1):316-35.

Sebens KP, DeRiemer K. Diel cycles of expansion and contraction in coral reef anthozoans. Mar Biol. 1977;43:247-56.

Stampar SN, Morandini AC. Occurrence of Isarachnanthus (Cnidaria: Anthozoa: Ceriantharia) at Ascension Island: a test of hypothesis. J Mar Biol Assoc United Kingdom. 2014;1-5. doi: 10.1017/S0025315414000423.

Stampar SN, Maronna MM, Vermeij MJA, Silveira FL, Morandini AC. Evolutionary diversification of banded tube-dwelling anemones (Cnidaria; Ceriantharia; Isarachnanthus) in the Atlantic Ocean. PLoS One. 2012. doi: 10.1371/journal. pone.0041091.

Stephenson TA. On certain Actiniaria collected off Ireland by the Irish Fisheries Department, during the years of 1899-1913. Proc R Irish Acad. 1918;34B:106-64.

Stephenson TA. On the classification of Actiniaria. Part I. Forms with acontia and forms with a mesogleal sphincter. Q J Microsc Sci. 1920;64:425-574.

Stephenson TA. On the classification of Actiniaria. Part III. Definitions connected with the forms dealt with in Part II. Q J Microsc Sci. 1922;66:247-319.

Stephenson TA. The British Sea Anemones, vol. II. London: The Ray Society; 1935.

Uchida H, Soyama I. Sea Anemones in Japanese Waters. Japan: TBS; 2001.

Varela C. Las anémonas (Anthozoa, Zoantharia: Actiniaria, Corallimorpharia y Zoanthiniaria) de la región occidental de Cuba. Cuba: Universidad de la Habana; 2001.

Varela C, Ortiz M, Lalana R. Primer registro de la familia Parazoanthidae y de Parazoanthus parasiticus (Cnidaria: Anthozoa: Zoanthiniaria) para aguas cubanas. Cart Inf los Zoólogos Invertebrados Cuba. 2003;13:5.

Varela C, Guitart B, Ortiz M, Lalana R. Los zoantídeos (Cnidaria, Anthozoa, Zoanthiniaria) de la Región Occidental de Cuba. Rev Investig. 2002;23:179-84.

Verrill AE. Revision of the Polypi of the eastern coast of United States. Mem Bost Soc Nat Hist. 1864;1:1-45.

Verrill AE. Madreporaria. Commun Essex Inst. 1867;5:33-50.

Verrill AE. Synopsis of the polyps and corals of the North Pacific Exploring Expedition, under Commodore C. Ringgold and Capt. John Rodgers, U.S.N., from 1853 to 1856 . Collected by Dr. Wm. Stimpson, Naturalist to the Expedition. Part IV. Actiniaria [First part]. Commun Essex Inst. 1868;5:315-30

Verrill AE. Review of the corals and polyps of the west coast of America. Trans Connect Acad Arts Sci. 1869;1:377-558.

Verrill AE. Descriptions of new American actinians, with critical notes on other species, I. Am J Sci Arts1. 1898;6:493-8.

Verrill AE. Descriptions of imperfectly known and new actinians, with critical notes on other species, II. Am J Sci Arts. 1899a;7:41-50.

Verrill AE. Descriptions of imperfectly known and new actinians, with critical notes on other species, III. Am J Sci Arts. 1899b;7:41-50.

Verrill AE. Additions to the Anthozoa and Hydrozoa of the Bermuda. Anthozoa. Trans Connect Acad Arts Sci. 1900;10:551-72.

Verrill AE. Additions to the fauna of Bermudas from the Yale Expedition of 1901, with notes on other species. Trans Connect Acad Arts Sci. 1901;11:15-62.

Verrill AE. The Bermuda Islands. Part IV. Geology and Peleontology, and Part V. An account of the coral reefs. Trans Connect Acad Arts Sci. 1905:12:45-348.

Verrill $A E$, editor. Additions to the fauna of the Bermudas from the Yale Expedition of 1901, with notes on other species. New Haven: Verrill, A.E; 1907. p. 15-62.

Watzl O. Die Actiniarien der Bahamainseln. Ark für Zool. 1922;14:1-89.

Weill R. Contribution a l'Étude des Cnidaires et de leurs Nématocystes. Paris: Les Presses Universitaires de France; 1934.

Weinland DF. Über Inselbildung durch korallen und Mangrovebüsche im mexikanischen Golf. Württembergische Naturwissenschaftliche Jahreshefte. 1860;16:31-44.

West DA. Symbiotic Zoanthids (Anthozoa: Cnidaria) of Puerto Rico. Bull Mar Sci. 1979:29:253-71.

Wilson HV. On a new actinia, Hoplophoria coralligens. Stud Biol Lab Johns Hopkins Univ. 1890;4:379-87.

Wirtz P. The sea anemone Telmatactis cricoides from Madeira and the Canary Islands: size frequency, depth distribution and colour polymorphism. Arquipélago Life Mar Sci. 1996;14A:1-5.

Wirtz P. Crustaceans symbionts of the sea anemone Telmatactis cricoides at Madeira and the Canary Islands. J Zool. 1997;242:799-811. 
Wirtz P. New Records of Marine Invertebrates From the Cape Verde. Arquipélago Life Mar Sci. 2001;18A:81-4.

Wirtz P. New records of marine invertebrates from São Tomé Island (Gulf of Guinea). J Mar Biol Assoc United Kingdom. 2003;83:735-6. doi:10.1017/ S0025315403007720h

Wirtz P. Thirteen new records of marine invertebrates and two of fishes from Cape Verde Islands. Arquipélago Life Mar Sci Life Mar Sci. 2009;26:51-6.

Zamponi MO. Estructuras adaptativas en anémonas (Coelenterata Actiniaria). Neotropica. 1981;27:165-9.

Zamponi MO, Pérez CD. Comparative morphological study of different species of Actiniaria between the intertidal zone from Mar del Plata and Santa Clara del Mar (Argentine). I. Phymactis clematis Dana, 1849 (Anthozoa: Actiniidae). Biociencias. 1996:4:91-102.

Zamponi MO, Belém MJC, Schlenz E, Acuña FH. Distribution and some ecological aspects of Corallimorpharia and Actiniaria from shallow waters of the South American Atlantic coasts. Phys A. 1998:55:31-45.

Zeiller W. Phylum Coelenterata. The Polyp animals. In: Zeiller W, editor. Trop. Mar. Invertebr. South. Florida Bahama Islands. New York: Wiley-Interscience Publications, John Wiley and Sons; 1974.

Submit your next manuscript to BioMed Central and we will help you at every step:

- We accept pre-submission inquiries

- Our selector tool helps you to find the most relevant journal

- We provide round the clock customer support

- Convenient online submission

- Thorough peer review

- Inclusion in PubMed and all major indexing services

- Maximum visibility for your research

Submit your manuscript at www.biomedcentral.com/submit
Biomed Central 